\title{
The Progress of Sustainable Management of Ammonia Emissions from Agriculture in European Union States Including Poland-Variation, Trends, and Economic Conditions
}

\author{
Anna Murawska ${ }^{1}$ and Piotr Prus ${ }^{2, *(D)}$ \\ 1 Department of Economics and Marketing, UTP University of Science and Technology in Bydgoszcz, \\ 85-790 Bydgoszcz, Poland; anna.murawska@utp.edu.pl \\ 2 Laboratory of Economics and Agribusiness Advisory, Department of Agronomy, Faculty of Agriculture \\ and Biotechnology, UTP University of Science and Technology in Bydgoszcz, 85-790 Bydgoszcz, Poland \\ * Correspondence: piotr.prus@utp.edu.pl
}

Citation: Murawska, A.; Prus, P. The Progress of Sustainable Management of Ammonia Emissions from Agriculture in European Union States Including Poland-Variation, Trends, and Economic Conditions.

Sustainability 2021, 13, 1035.

https://doi.org/10.3390/su13031035

Received: 9 December 2020

Accepted: 13 January 2021

Published: 20 January 2021

Publisher's Note: MDPI stays neutral with regard to jurisdictional claims in published maps and institutional affiliations.

Copyright: (C) 2021 by the authors Licensee MDPI, Basel, Switzerland. This article is an open access article distributed under the terms and conditions of the Creative Commons Attribution (CC BY) license (https:// creativecommons.org/licenses/by/ $4.0 /)$.

\begin{abstract}
Ammonia $\left(\mathrm{NH}_{3}\right)$ is one of the gases adversely affecting the natural environment. The greatest contributor to emissions of this gas to the atmosphere is agricultural activity. The main objective of the study was to assess the progress of sustainable management of ammonia emissions from agriculture in European Union countries. The specific objectives of the article were the following: to analyse and diagnose the level of ammonia emissions from agriculture, to study the diversity of emissions of this gas between countries, to analyse trends in the years 2010-2017 and, above all, to assess the relationship between the level of ammonia emissions from agriculture and the economic conditions of EU countries. The theoretical part of the article describes the causes and effects of, as well as preventive actions against, ammonia emissions from agriculture, whereas the empirical part analyses the problems, trends, variations, and the impact of economic conditions on emissions of this gas in 2010-2017. To evaluate the range of problems discussed, indicators describing ammonia emission levels $\mathrm{Y}_{01 \mathrm{~A}}$ and $\mathrm{Y}_{01 \mathrm{~B}}$, as well as indicators characterising economic conditions $\mathrm{X}_{01}, \mathrm{X}_{02}$, and $\mathrm{X}_{03}$ have been employed. During the study, the following indicators were analysed: ammonia emissions from agriculture in kilograms per hectare $\left(\mathrm{Y}_{01 \mathrm{~A}}\right)$, ammonia emissions from agriculture-percentage of total emissions $\left(\mathrm{Y}_{01 \mathrm{~B}}\right)$, government appropriations or outlays on research and development in agriculture in EUR per capita $\left(\mathrm{X}_{01}\right)$, agricultural factor income in EUR per annual work unit (AWU) $\left(\mathrm{X}_{02}\right)$, and real GDP in EUR per capita $\left(\mathrm{X}_{03}\right)$. The source for the empirical data was information from the European Statistical Office (Eurostat). The analysis covered 28 states of the European Union. In the article, among others, the rate of change indices, coefficients of variation $\left(V_{s}\right)$, measures of distance (D) and range (R), coefficients of asymmetry (A) and kurtosis (K) were calculated, and correlation and regression analysis were performed. The share of agriculture in total ammonia emissions in European Union countries is very high and averages as high as $92 \%$. Most of the countries maintain an upward tendency; a disturbing fact, considering such high ammonia emissions from agriculture. Based on the present analysis, it has also been confirmed that countries with the relatively highest levels of economy and agricultural research and development funding in fact emit more and increasingly more ammonia from agriculture. To avoid the intensification of the adverse effects of this phenomenon, all EU Member States should take effective, efficient, and sustained action to reduce ammonia emission levels.
\end{abstract}

Keywords: ammonia; emissions; agriculture; environment; sustainable development; European Union; economic conditions; economic growth

\section{Introduction}

One of the greatest challenges of our times is the climate crisis. The effects of global warming are undisputable. The World Meteorological Organisation [1] has once again announced that the last five years were the warmest in history and that 2019 was the second hottest year, after 2016, in a series of exceptionally hot years in the whole world. According 
to the European State of the Climate [2] report, Europe is the continent that is warming the fastest. The unfavourable climate changes are predominantly caused by rising emissions of greenhouse gases and ammonia, also in the Baltic Sea region [3]. This is entailed by unlimited and ubiquitous human activity. Contributors to harmful pollution of the natural environment are the combustion of fossil fuels for energy, deforestation, decomposition of organic matter in landfills (usually created due to wasting and throwing out food), and other consumption waste $[4,5]$.

Increased emissions of harmful greenhouse gases, ammonia, and other environmental waste, including particulate matter and heavy metals, result mainly from the processes of intensification and concentration of agricultural production [6,7]. The source of these emissions is mostly an increasing consumption of the means of production, such as fertilisers, pesticides, fuel and energy, natural fertiliser management, agrotechnical procedures, and post-harvest residue burning [8]. As Tian et al. [9] have emphasised, the rising consumption of nitrogen fertilisers in world food production poses a threat for the fulfilment of climate objectives and assumptions arising from the Paris Agreement, while a rising need for food and animal feed will intensify the increase in natural environmental pollution.

Economic growth, and in particular, the increase in intensification of agricultural production in developed countries, is a priority and, oftentimes, the external costs of agriculture are overlooked [10]. The hope for change is that countries are gradually taking steps to reduce the burden on the environment. However, are all the countries of the European Union genuinely taking effective measures to reduce emissions of harmful pollutants from production, including agricultural production? Do all countries effectively manage ammonia emissions from agriculture? In view of the above, the purpose of this article was to analyse and evaluate the management of ammonia emissions from agriculture, the trends occurring in this respect in the years 2010-2017, differences between countries, and the impact of economic conditions on the emissions of this gas. The article analyses the progress in the sustainable management of ammonia emissions in the European Union. Additionally, the authors drew attention to countries with the minimum and the maximum ammonia emission values and specified the role of Poland as an example of a country located in the Baltic Sea region with significant importance to agriculture and the food sector. In 2018, the global value placed Polish agriculture in seventh place in the European Union, behind France, Germany, Italy, Spain, Great Britain, and the Netherlands [11]. The accomplishment of the objective was meant to enable verification of the hypothesis, assuming that the lack of progress in effective reduction of the level of ammonia emissions from agriculture is observed in all EU Member States, and an upward trend in emissions of this gas is primarily seen in developed countries with high economic development, high workforce productivity, and government support to agricultural research and development. The accomplishment of the main objective of the article was preceded by a review of literature on the causes of ammonia emissions from agriculture, resultant threats, and actions taken to reduce the emissions of this gas.

\section{Theory and Background}

One of the main pollutants emitted into the Earth's atmosphere is ammonia. Ammonia ( $\mathrm{NH}_{3}$, azane, trihydridonitrogen) [12] is an inorganic chemical compound of nitrogen and hydrogen that is formed as a result of bacterial and enzymatic processes of the decomposition of protein substances, including amino acids, amides, urea, and uric acid. Ammonia is a colourless, reactive gas, lighter than air, and easily soluble in water. It is formed in a number of biological and industrial processes. It is found in trace quantities in the Earth's atmosphere. About $99 \%$ of ammonia comes from the decomposition of waste organic matter [13].

Agricultural activity has been the most prominent contributor to the supply of ammonia to the Earth's atmosphere [14,15]. In the European Union, agriculture is responsible for over $92 \%$ of the emissions of this gas, while in Poland, this value reaches 94\% [16]. The share of other sectors in $\mathrm{NH}_{3}$ emissions is negligible. Combustion processes outside this industry emit 
$2.5 \%$ of this gas: road transport- $-1.5 \%$, and combustion processes within industry- $-1.2 \%$. The largest part of ammonia emissions produced in agriculture is related to livestock manure$78 \%$, including the use of natural fertilisers $-49 \%$. The remaining $22 \%$ of the emissions are related to the use of mineral nitrogen fertilisers in utilised agricultural areas $[17,18]$.

The formation of ammonia in agricultural production in a given region and its emissions to the atmosphere depends on many factors. These include the type of animal species farmed and their housing systems [19], nitrogen content in animal diets, methods of storage of natural fertilisers, crop types as well as the type, dose, and application technology of fertilisers used, and also weather conditions [14,20-22].

The main source of ammonia emissions is natural fertiliser in the form of slurry and manure [23,24]. For example, in Poland, these fertilisers are produced mainly as a result of cattle, pig, and horse farming [25]. At a farm, in livestock buildings, nitrogen losses in the form of ammonia amount to approximately $10 \%$ [26]. At the stage of natural fertiliser storage, ammonia losses range from $20 \%$ to $45 \%[27,28]$. These losses, however, can be effectively reduced by staged laying (instead of simultaneous laying over the whole area) and pressing (compacting) the heap. Compacting and covering the manure heap might reduce $\mathrm{NH}_{3}$ emissions by up to $90 \%$ during the first summer storage period [27]. Losses during natural fertiliser application on arable land range from about 15\% [29] to even $95 \%$ [30,31], and on grazing land, they can amount to approximately $15 \%$ [25,30]. It is also estimated that the ammonia losses from liquid natural fertilisers after their application to utilised agricultural areas are much higher than from manure [29]. Incorporation of slurry into the soil within minutes after application leads to a $70 \%-90 \%$ reduction of $\mathrm{NH}_{3}$ emissions. When mixed with soil within $4 \mathrm{~h}$ after application, the reduction of $\mathrm{NH}_{3}$ emissions is estimated to be at 45-65\%, and within $24 \mathrm{~h}-$ at 30\% [32]. Another procedure effectively reducing $\mathrm{NH}_{3}$ emissions from slurry is slurry acidification. In Europe, slurry acidification is commonly used in Denmark [33,34]. Studies conducted in Denmark have shown that ammonia losses from acidified slurry after application, on average, are $50 \%$ lower compared to unacidified slurry [35]. Nitrogen losses from slurry stored without acidification for 6 months (winter) and 13 months (winter, spring, and summer) were 5\% and $45 \%$, respectively, while nitrogen losses from acidified slurry were less than $1 / 10$ of these losses [36]. Similar results were achieved in studies conducted in Poland [37]. The reduction of $\mathrm{NH}_{3}$ emissions depends not only on the properties of slurry and meteorological conditions during its application but primarily on low-emission practices (techniques) of its utilisation [15].

The remaining $22 \%$ of ammonia emissions are related to the use of mineral nitrogen fertilisers in utilised agricultural areas [18]. Mineral fertilisers are among the most important yield-forming factors in plant production, provided that their usage is sustainable. Losses of nitrogen in the form of ammonia from mineral nitrogen fertilisers may vary considerably, depending on soil and climate conditions, application technique, and type of fertiliser applied. Losses from nitrogen fertilisers, such as ammonium phosphate, ammonium sulphate, urea, and urea solutions, are estimated to be at $5-40 \%$ depending on the conditions. On the other hand, losses from ammonium nitrate are smaller, of the order of $0.5-5 \%$ of the total amount of nitrogen used [38].

Ammonia released from nitrogen fertilisers occurs as a result of urea decomposition under the influence of soil and air moisture, and varies depending on soil properties. It is estimated that up to $60 \%$ of nitrogen contained in urea can be lost through volatilisation, that is, direct evaporation from the soil surface [39]. Although ammonia is very quickly removed from the air, owing to its very high water solubility, it can indirectly be a source of nitrous oxide, which remains in the atmosphere for a very long time-even as long as 120 years $[9,40]$.

Ammonia emissions may be reduced by choosing an adequate application time for the nitrogen-containing fertiliser. Ammonia emissions are highest in warm, dry and windy conditions. They can be reduced by optimising the application schedule. It is recommended, among other things, to apply the fertilisers in cool and humid conditions, in the evenings, 
when wind speed and temperatures are lower, before or during light rain, as well as to avoid application during warm weather conditions, especially during periods when the sun is at its peak, that is, when solar radiation is strongest. This can be done in a modern form by Application Timing Management Systems (ATMS). These are computer models that calculate the number of fertiliser components lost during and after the application of natural fertilisers, based on average regional environmental conditions. Potential benefits in terms of emission reductions achievable with this solution vary depending on regional and local soil and climate conditions [41].

Ammonia emissions from agricultural sources have a number of adverse consequences; including the following, inter alia [13,42]:

- cause a loss of nitrogen in animal faeces and mineral nitrogen fertilisers,

- contribute to the eutrophication, or over-nutrification, of the marine environment,

- contributes to the formation of acid rain, which is a threat to natural terrestrial and aquatic ecosystems,

- has a negative impact on human health,

- accelerates corrosion of metal structures and sandstone buildings.

In addition, the incompetent application of fertilisers in utilised agricultural areas leads to the over-fertilisation of plants with nitrogen, nutrient leaching and, as a consequence, emissions of nitrogen compounds to the atmosphere [38]. The nitrogen released with ammonia enables the rapid development of algae and cyanobacteria, which consequently limits oxygen supply, leading to the degradation of water reservoirs. Soil acidification may lead to a decrease in the assimilability of nutrients necessary for plant development. Moreover, this phenomenon may increase the mobility of elements dangerous to humans and plants, mainly heavy metals, and limit the activity of microorganisms. Ammonia emitted into the air, which may return in dry or wet precipitation, is also a toxic threat to crops and may increase the sensitivity of crops to stress factors [22]. Therefore, it is important to manage crops that will lead to significant advances in the sustainable development of agroecosystems. One way is, inter alia, to increase biodiversity in agriculture [43,44].

The problem of the adverse effects of ammonia emissions was recognised in Europe as early as the 1970s, resulting in the signing of the Convention on Long-Range Transboundary Air Pollution, commonly known as the Geneva Convention, on 13 November 1979 [45]. The objective of the Convention was to protect people and the environment from air pollution by reducing emissions and preventing air pollution, including the long-range transboundary movement of pollutants. It covers pollutants such as sulphur compounds, nitrogen oxides, ammonia, volatile organic compounds, heavy metals, persistent organic pollutants, and particulates. Currently, the key document for reducing ammonia emissions and achieving the European Union's long-term policy objective of improving air quality to a level that does not cause significant negative effects or risk to human health and the environment is the directive of the European Parliament and of the Council of 14 December 2016 on the reduction of national emissions of certain atmospheric pollutants (known as the NEC Directive) [46]. This directive lays down obligations for Member States to reduce the emissions of anthropogenic pollutants into the atmosphere and requires them to draw up, adopt, and implement national programmes to control air pollution and monitor the emissions of the pollutants and their effects. Meanwhile, in 2017, the European Commission Implementing Decision that established the best available techniques (BAT) conclusions for the intensive rearing of poultry or pigs pursuant to Directive 2010/75/EU of the European Parliament and of the Council [47] was adopted, and in 2018, the European Commission Implementing Decision that laid down a common format for national air pollution control programmes under the NEC Directive of 2016 [48] was adopted as well.

In order to achieve the reduction targets set out in the NEC Directive, it is necessary to implement measures in this sector. In Poland, for example, in 2019, "kodeks doradczy dobrej praktyki rolniczej dotyczącej ograniczania emisji amoniaku" (Advisory Code of Good Agricultural Practice for Limiting Ammonia Emissions) was developed by the Institute of Technology and Life Sciences in Falenty [22] to indicate the specific actions 
resulting in reduced $\mathrm{NH}_{3}$ emissions. The authors of the Code prepared guidelines for the reasonable management of nitrogen and ammonia emissions by farmers during the process of plant and animal production on a farm. The paper proposes nutritional methods of limiting ammonia emissions from animal production, low-emission animal housing systems, low-emission systems for storage and application of natural fertilisers, as well as ways of limiting ammonia emissions during the application of mineral fertilisers. Moreover, farmers may avail themselves of "zbiór zaleceń dobrej praktyki rolniczej mającej na celu ochronę wód przed zanieczyszczeniem azotanami pochodzacymi ze źródeł rolniczych" ("a collection of good agricultural practice recommendations for the protection of water against pollution with nitrates from agricultural sources") prepared by IUNG-PIB (Institute of Soil Science and Plant Cultivation State Research Institute) in Puławy [49]. Furthermore, in 2018, Poland adopted the Regulation of the Council of Ministers on "program działań mających na celu zmniejszenie zanieczyszczenia wód azotanami pochodzacymi ze źródeł rolniczych oraz zapobieganie dalszemu zanieczyszczeniu" ("action program aimed at reducing water pollution by nitrates from agricultural sources and preventing further such pollution") [50]. This regulation obliges all entities carrying out agricultural production, including special sections of agricultural production, and activities involving the storage of animal manure or application of fertilisers, to carry it out in such a way as to prevent water pollution with nitrates. Based on the "Krajowy program ograniczania zanieczyszczenia powietrza" (National Air Pollution Control Programme) drawn up in 2019 (Annex based on Article 6 of Directive (EU) 2016/2284, p. 30), in particular, in regard to the reduction of ammonia emissions, actions involving soil injection of urea-based fertilisers, the spreading of slurry by means other than spraying, and the incorporation of manure within $12 \mathrm{~h}$ are to be promoted among farmers. The NEC Directive lays down obligations for Member States to reduce emissions of anthropogenic pollutants into the atmosphere and requires them to draw up, adopt, and implement national programmes to control air pollution and monitor emissions of the pollutants and their effects. For example, according to the Projection 2019, Poland has undertaken a goal to reduce ammonia emissions by $1 \%$ each year from 2020 to 2029 , and by $17 \%$ in 2030 [51].

A review of the literature on the causes of ammonia emissions from agriculture and the resulting threats shows that agriculture plays a key role as an emitter of this gas in regard to the idea of achieving the sustainable development goals. Agriculture plays primarily a food function and it is impossible to replace the productive function of agriculture with laboratory or factory methods of food production. It should be borne in mind that reducing ammonia emissions from agriculture is very difficult, as part of the emissions are inextricably linked to livestock farming. Apart from the measures taken to reduce ammonia emissions, it is important to take adaptation measures. Limiting the risk related to the impact of agriculture on climate change requires the involvement of public funds in the development processes of this sector and monitoring the impact of the economic development of countries on the level of harmful gas emissions by agriculture.

\section{Purpose of the Article, Hypothesis, and Materials and Methods}

Given the significant contribution of agriculture to the production of numerous external expenses [10] that are negative for society and the environment, the main objective of this study was to analyse and diagnose the progress of sustainable management of ammonia emissions in rural areas of European Union states. As part of the detailed objectives, analysis and evaluation of the following were performed: the level of ammonia emissions from agriculture, differences between countries in the European Union in this regard, trends in 2010-2017, and the relationship between ammonia emissions from agriculture and the economic development of countries and other economic factors characterising agriculture. The accomplishment of the objective was meant to enable the verification of the hypothesis, assuming that the lack of progress in effective reductions of ammonia emission levels would be observed in all EU Member States, and an upward trend in emissions of this gas would be primarily seen in countries with the relatively highest 
levels of economic development and other economic indicators, such as GDP per capita, workforce productivity in the agricultural sector, or government support for agricultural research and development.

The analyses were based on available indicators, collected by the European Statistical Office (Eurostat), used to monitor the achievement of sustainable development targets [16]. In order to attain the objectives of the article, indicators were selected and gathered and, consequently, a database was created in Microsoft Excel and Statistica PL. A numerical database of indicators characterising the level of ammonia emissions from agriculture $\left(\mathrm{Y}_{01 \mathrm{~A}}, \mathrm{Y}_{01 \mathrm{~B}}\right)$ and indicators characterising economic conditions $\left(\mathrm{X}_{01}, \mathrm{X}_{02}, \mathrm{X}_{03}\right)$ was prepared. The following indicators were analysed: ammonia emissions from agriculture in kilograms per hectare $\left(\mathrm{Y}_{01 \mathrm{~A}}\right)$, ammonia emissions from agriculture-percentage of total emissions $\left(\mathrm{Y}_{01 \mathrm{~B}}\right)$, government appropriations or outlays on research and development in agriculture in EUR per capita $\left(X_{01}\right)$, agricultural factor income in EUR per annual work unit (AWU) $\left(\mathrm{X}_{02}\right)$, and real GDP in EUR per capita $\left(\mathrm{X}_{03}\right)$ (Table 1$)$. The selection of indicators was based on an expert method that consisted of conducting discussions with independent experts on the validity of the selection of variables. The agreements concerned both the variables describing the level of ammonia emissions $\left(\mathrm{Y}_{01 \mathrm{~A}}, \mathrm{Y}_{01 \mathrm{~B}}\right)$ and economic factors $\left(\mathrm{X}_{01}, \mathrm{X}_{02}, \mathrm{X}_{03}\right)$. The decision to select specific indicators was dependent on the availability of complete and up-to-date data for all $28 \mathrm{EU}$ countries and a positive evaluation of the selection by experts.

The indicators gathered were subdivided into dependent variables $Y\left(Y_{01 A}, Y_{01 B}\right)$ and independent variables $X\left(X_{01}, X_{02}, X_{03}\right)$. These subdivisions of indicators were used to check whether there is a link between variations-the variation in indicators characterising the overall economic situation of the country (GDP per capita) and the level of agricultural income, agricultural research, development expenditure, and the variation in ammonia emissions from agriculture in EU countries.

Information gathered by the European Statistical Office (Eurostat) was the source of the empirical data. The analysis covered 28 European Union states. The article makes use of abbreviations for names of the EU Member States, compliant with ISO 3166 Alpha-2 codes developed by the International Standardisation Organisation [49]: Austria (AT), Belgium (BE), Bulgaria (BG), Croatia (HR), Cyprus (CY), the Czech Republic (CZ), Denmark (DK), Estonia (EE), Finland (FI), France (FR), Greece (GR), Spain (ES), Ireland (IE), Lithuania (LT), Luxembourg (LU), Latvia (LV), Malta (MT), the Netherlands (NL), Germany (DE), Poland (PL), Portugal (PT), Romania (RO), Slovakia (SK), Slovenia (SI), Sweden (SE), Hungary (HU), the United Kingdom (GB), Italy (IT). [52]. During the analysis, EU countries with the minimum and maximum ammonia emission values were described. The authors additionally presented the role of Poland as an example of a large country located in the Baltic Sea region with significant importance to the agriculture and food sector. The studied period was 2010-2017.

The data were analysed statistically. The article presents the basic descriptive statistics of the studied group of the EU countries. Among others, the rate of increase or decrease of $I_{t}$, the coefficients of variation $\left(V_{s}\right)$, measures of distance $(D)$ and range $(R)$, the coefficients of asymmetry (A) and kurtosis $(\mathrm{K})$ were calculated, and correlation and regression analysis were performed $[53,54]$. The calculation of the rate of increase or decrease of $I_{t}$ was intended to express the level of increase in ammonia emissions in 2017 compared to the base year, $2010\left(I_{t}=t_{2017}-t_{2010} \times 100-100\right)$. Increased values greater than zero indicate an increase in ammonia emissions, and values lower than zero indicate a decrease in emissions. The coefficient of variation was used to assess the variability (differentiation) of the studied countries: $V_{S}\left(V_{S}=S / \bar{x} * 100 \%\right)$, where $\bar{x}$ and $S$ denote arithmetic mean and standard deviation, respectively. The differentiation between the EU countries in terms of ammonia emissions was significant when $\mathrm{V}_{\mathrm{s}}>10 \%$. Other measures assessing the differentiation between countries were the measure of distance $(\mathrm{D}=\mathrm{max} / \mathrm{min})$ and the measure of the range $(\mathrm{R}=$ max $-\mathrm{min})$. The measure of asymmetry $(\mathrm{A})$ was used to assess which of the EU countries were above or below the average level of the investigated dependent variable (Y). Histograms and measures of kurtosis were calculated in order to assess the concentration 
of results around the EU average. Correlation and regression analysis were also performed during the study. With the help of these analyses, attempts were made to check whether there were significant interdependencies between the dependent variables describing the level of ammonia emissions $\left(\mathrm{Y}_{01 \mathrm{~A}}, \mathrm{Y}_{01 \mathrm{~B}}\right)$ and independent economic conditions $\left(\mathrm{X}_{01}, \mathrm{X}_{02}\right.$, $\left.\mathrm{X}_{03}\right)$, and whether the emissions increased or decreased with the increase in the level of economic conditions.

Table 1. Indicators allowed for an evaluation of the progress of sustainable management of ammonia emissions from agriculture (dependent variables-Y) and their economic conditions (independent variables-X) in EU countries (28) in 2010-2017.

\begin{tabular}{|c|c|c|c|}
\hline Variable & Year & Variable Name & Variable Description \\
\hline \multicolumn{4}{|c|}{$\begin{array}{l}\text { Indicators characterising the level of ammonia emissions in agriculture in European Union countries in 2010-2017-the } \\
\text { effects of promoting sustainable management of resources in agriculture }\end{array}$} \\
\hline$Y_{01 A}$ & $2010-2017$ & $\begin{array}{l}\text { Ammonia }\left(\mathrm{NH}_{3}\right) \text { emissions from agriculture } \\
\text { in kilograms per hectare }\end{array}$ & $\begin{array}{l}\text { The indicator measures ammonia }\left(\mathrm{NH}_{3}\right) \text { emissions } \\
\text { as a result of agricultural production. Ammonia } \\
\text { emissions per hectare were calculated using the total } \\
\text { utilised agricultural area (UAA) of the relevant year } \\
\text { as the denominator. }\end{array}$ \\
\hline$Y_{01 B}$ & $2010-2017$ & $\begin{array}{l}\text { Ammonia }\left(\mathrm{NH}_{3}\right) \text { emissions from } \\
\text { agriculture-percentage of total emissions } \\
\text { (source: EEA) [55] }\end{array}$ & $\begin{array}{l}\text { The indicator tracks trends in anthropogenic } \\
\text { atmospheric emissions of ammonia by agriculture. }\end{array}$ \\
\hline \multicolumn{4}{|c|}{$\begin{array}{l}\text { Indicators characterising economic situations of countries and the level of income earned from agriculture and outlays on } \\
\text { research and development in agriculture in European Union countries in 2010-2019 }\end{array}$} \\
\hline$x_{01}$ & 2010-2019 & $\begin{array}{l}\text { Government support for agricultural } \\
\text { research and development in EUR per capita }\end{array}$ & $\begin{array}{l}\text { The indicator refers to government appropriations } \\
\text { or outlays on research and development (R\&D). }\end{array}$ \\
\hline$X_{02}$ & $2010-2018$ & $\begin{array}{l}\text { Agricultural factor income in EUR per } \\
\text { annual work unit (AWU) }\end{array}$ & $\begin{array}{l}\text { The indicator is a partial labour productivity } \\
\text { measure of the agricultural sector. Agricultural } \\
\text { factor income measures the income generated by } \\
\text { farming, which is used to remunerate borrowed or } \\
\text { rented factors of production (capital, wages, and } \\
\text { land rents) as well as own production factors (own } \\
\text { labour, capital, and land). }\end{array}$ \\
\hline$x_{03}$ & 2010-2019 & Real GDP per capita in EUR & $\begin{array}{l}\text { The indicator is calculated as the ratio of real GDP to } \\
\text { the average population of a specific year. GDP } \\
\text { measures the value of total final output of goods and } \\
\text { services produced by an economy within a certain } \\
\text { period of time. }\end{array}$ \\
\hline
\end{tabular}

Source: own work based on [16].

\section{Results}

One of the indicators taken into account in the study on the progress of sustainable management of ammonia $\left(\mathrm{NH}_{3}\right)$ emissions from agriculture in European Union countries is the level of emissions of this gas in kilograms per hectare of utilised agricultural area $\left(\mathrm{Y}_{01 \mathrm{~A}}\right)$. Ammonia emissions measured in this way increased on average in the EU in the analysed period of 2010-2017 by 3.6 p.p. In 2017, ammonia emissions were $20.3 \mathrm{~kg} / \mathrm{ha}$, while in 2010, they were $19.6 \mathrm{~kg} / \mathrm{ha}$. While the ammonia emissions evaluated using this indicator increased in the subsequent studied years, the variation between EU countries in this respect was decreased, which was confirmed by the calculated coefficients of variation (in 2010, $\mathrm{V}_{\mathrm{s}}=85.5 \%$, and in 2017, $\mathrm{V}_{\mathrm{s}}=76.8 \%$ ), $\mathrm{D}$ (in 2010, $\mathrm{D}=15.4$, and in 2017, $\mathrm{D}=12.6$ ), and $\mathrm{R}$ (in 2010, $\mathrm{R}=103.5 \mathrm{~kg} / \mathrm{ha}$, and in $2017, \mathrm{R}=84.7 \mathrm{~kg} / \mathrm{ha}$ ). The country with the lowest ammonia emissions in kilograms per hectare was Latvia (in 2017, 7.3 kg/ha), and Malta had the highest emissions (in 2017, $92.0 \mathrm{~kg} / \mathrm{ha}$ ). In Poland, the ammonia emissions measured with the $\mathrm{Y}_{01 \mathrm{~A}}$ indicator were close to the EU (28) average, and in 2017, they were equal to $19.9 \mathrm{~kg} / \mathrm{ha}$ (Table 2). 
Table 2. Ammonia $\left(\mathrm{NH}_{3}\right)$ emissions from agriculture (in kg/ha) in 2010-2017 in EU (28) countries—statistics.

\begin{tabular}{|c|c|c|c|c|c|c|c|c|c|}
\hline \multicolumn{10}{|c|}{ Ammonia $\left(\mathrm{NH}_{3}\right)$ Emissions from Agriculture (in kg/ha) } \\
\hline Year & 2010 & 2011 & 2012 & 2013 & 2014 & 2015 & 2016 & 2017 & $I_{t 2017}(2010=100)$ \\
\hline $\mathrm{EU}(28)$ total & 19.6 & 19.7 & 19.7 & 19.7 & 19.9 & 20.1 & 20.3 & 20.3 & 3.6 \\
\hline$y_{\text {min }}$ Latvia LV & 7.2 & 7.1 & 7.2 & 7.3 & 7.5 & 7.4 & 7.2 & 7.3 & 1.4 \\
\hline$y_{\max }$ Malta MT & 110.7 & 99.1 & 100.8 & 100.3 & 99.3 & 98.5 & 94.9 & 92.0 & -16.9 \\
\hline Poland PL & 19.3 & 19.1 & 18.8 & 19.0 & 18.7 & 18.5 & 18.9 & 19.9 & 3.1 \\
\hline $\mathrm{V}_{\mathrm{s}}$ & 85.5 & 80.3 & 80.4 & 80.4 & 79.4 & 78.5 & 77.9 & 76.8 & - \\
\hline $\mathrm{D}$ & 15.4 & 14.0 & 14.0 & 13.7 & 13.2 & 13.3 & 13.2 & 12.6 & - \\
\hline $\mathrm{R}$ & 103.5 & 92.0 & 93.6 & 93.0 & 91.8 & 91.1 & 87.7 & 84.7 & - \\
\hline K1 & 12.7 & 12.9 & 12.6 & 12.4 & 13.0 & 12.7 & 12.7 & 12.5 & - \\
\hline $\mathrm{M}$ & 18.9 & 18.6 & 18.4 & 18.7 & 18.7 & 18.7 & 19.0 & 19.6 & - \\
\hline K3 & 30.2 & 30.9 & 31.4 & 30.5 & 29.6 & 29.9 & 30.6 & 29.6 & - \\
\hline $\mathrm{A}_{\mathrm{s}}$ & 2.4 & 2.1 & 2.2 & 2.2 & 2.1 & 2.2 & 2.0 & 1.9 & - \\
\hline K & 6.9 & 5.1 & 6.0 & 5.9 & 5.6 & 6.0 & 4.6 & 4.2 & - \\
\hline
\end{tabular}

${ }^{*}$ Key: $y_{\min }-$ minimum value for the country, $y_{\max }-$ maximum value for the country, $\mathrm{V}_{\mathrm{s}}$-coefficient of variation in \% for EU (28) countries,

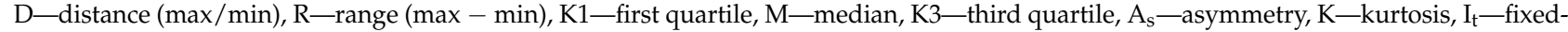
base index $\mathrm{I}_{t}(2017 / 2010 \times 100-100)$ in $\%$. Source: own work based on [16].

Positive asymmetry (skewness) coefficients A and histograms for the dependent variable $\mathrm{Y}_{01 \mathrm{~A}}$ clearly indicate a right-skewed distribution. Therefore, it can be concluded that many more countries (16) had values of the analysed indicator lower than the EU average. On the other hand, the high positive value of kurtosis, that is, a measure of tailedness of the distribution of objects, indicates a high concentration of groupings (countries, studied objects) around the average value, which means that the vast majority of the countries had values of $Y_{01 A}$ close to the EU average (Table 2 and Figure 1).

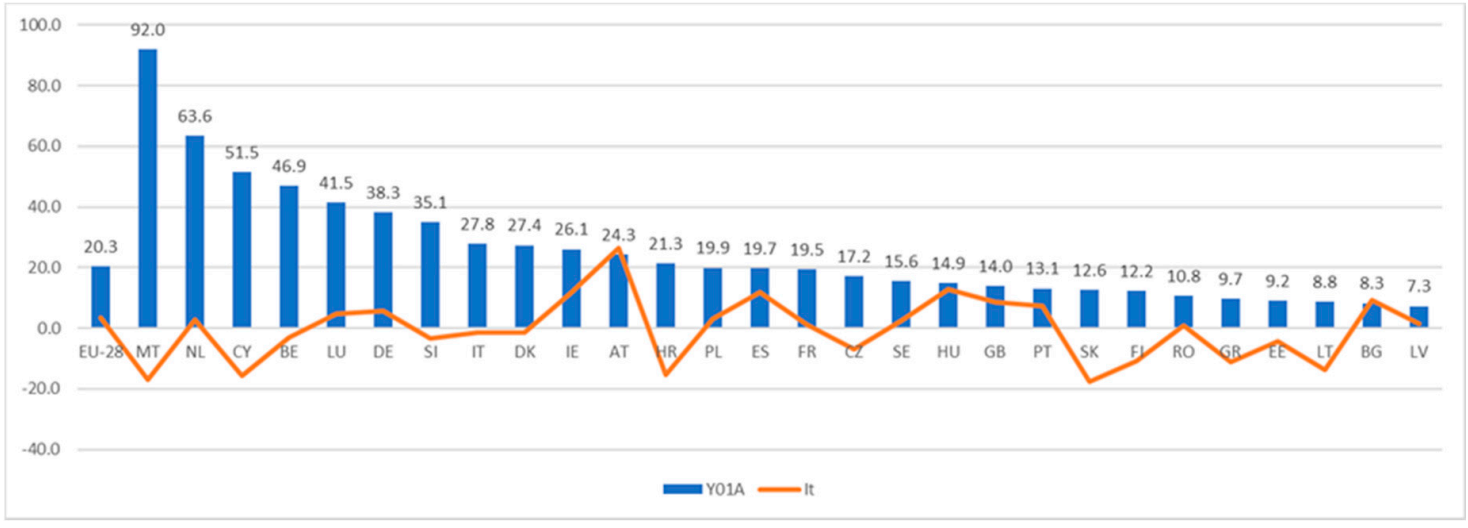

Figure 1. A ranking of countries according to their ammonia $\left(\mathrm{NH}_{3}\right)$ emissions from agriculture in $\mathrm{kg} / \mathrm{ha}\left(\mathrm{Y}_{01 \mathrm{~A}}\right)$ in EU countries (28) in 2017 and the fixed-base index $I_{t}$ (of increase or decrease) of emissions in 2017; base year, 2010=100. Source: own work based on [16].

On the basis of the calculations, it can be observed that in Malta, where ammonia emissions were relatively the highest, they decreased by as much as $16.9 \%$ compared to 2010 , which is a positive trend. However, it is alarming that the reduction in ammonia emissions does not apply to all countries with the highest values of the indicator under consideration, such as the Netherlands, Cyprus, Belgium, Luxembourg, Germany, or Slovenia. For example, between 2010 and 2017, in the Netherlands, nitrogen emissions in kilograms per hectare of the utilised agricultural area increased by $2.7 \%$, in Luxembourg, by $4.8 \%$, and in Germany, 
by as much as $5.8 \%$. Interestingly, a much more frequent decrease in ammonia emissions from agriculture measured in kilograms per hectare can be observed in countries with values of this indicator that were much lower than the EU average, for example, Finland, Slovakia, Greece, Estonia, and Lithuania. The countries where ammonia emissions in kilograms per hectare in 2010-2017 increased the most were Austria (by as much as 26.6\%), Hungary $(+12.9 \%)$, Ireland $(+12.0 \%)$, and Spain $(+11.9 \%)$. Conversely, the largest emission drops over the studied period were recorded in Slovakia $(-17.6 \%)$, Malta $(-16.9 \%)$, as mentioned above, Cyprus $(-15.7 \%)$, Croatia $(-15.5 \%)$, and Italy $(-13.7 \%)$ (Figure 2$)$.

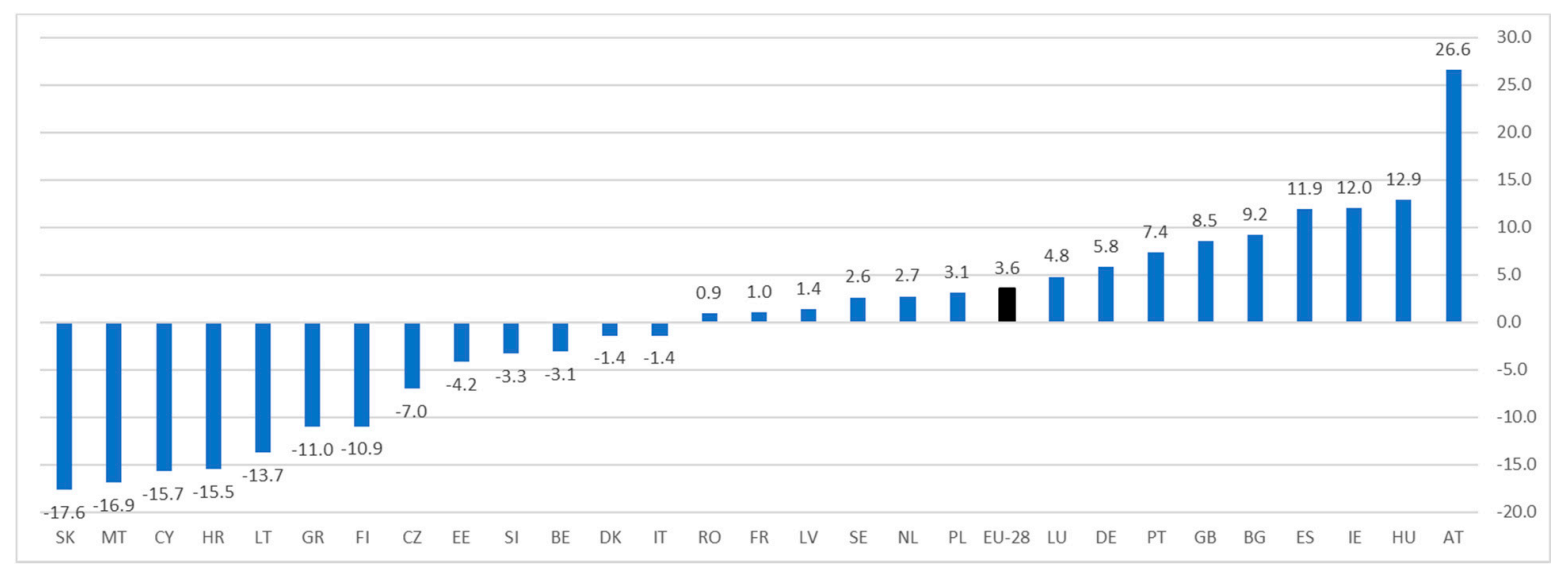

Figure 2. Fixed-base index $\mathrm{I}_{\mathrm{S}}$ calculated for the variable $\mathrm{Y}_{01 \mathrm{~A}}$; ammonia $\left(\mathrm{NH}_{3}\right)$ emissions in $\mathrm{kg} / \mathrm{ha}$ in EU countries (28) in 2017; base year, $2010=100$. Source: own work based on [16].

The second indicator taken into account in the study on the progress of EU countries in the sustainable management of ammonia emissions from agriculture between 2010 and 2017 is the level of ammonia $\left(\mathrm{NH}_{3}\right)$ emissions from agriculture as a percentage of total emissions of this gas $\left(\mathrm{Y}_{01 \mathrm{~B}}\right)$. As can be seen in Table 3, in 2017, as a result of agriculture, the EU countries in total emitted as much as $92.0 \%$ of this gas as a percentage of total ammonia emissions from all possible sources. Of concern is the fact that, with an already high share of emissions compared to 2010, there was a slight further increase of $0.8 \%$.

Table 3. Ammonia $\left(\mathrm{NH}_{3}\right)$ emissions from agriculture-\% of total emissions in 2010-2017 in EU (28) countries—statistics.

\begin{tabular}{|c|c|c|c|c|c|c|c|c|c|}
\hline \multicolumn{10}{|c|}{ Ammonia $\left(\mathrm{NH}_{3}\right)$ Emissions from Agriculture- $\%$ of Total Emissions } \\
\hline Year & 2010 & 2011 & 2012 & 2013 & 2014 & 2015 & 2016 & 2017 & $I_{t 2017}(2010=100)$ \\
\hline EU(28) total & 91.3 & 91.5 & 91.6 & 91.7 & 92.1 & 92.0 & 92.0 & 92.0 & 0.8 \\
\hline$y_{\text {min }}$ Portugal PT & 78.6 & 79 & 79.7 & 79.9 & 80.5 & 81.2 & 81.7 & 81.7 & 3.9 \\
\hline$y_{\max }$ Ireland IE & 98.3 & 98.4 & 98.6 & 98.7 & 98.7 & 98.8 & 99.0 & 99.1 & 0.8 \\
\hline Poland PL & 93.0 & 93.1 & 93.1 & 93.2 & 93.5 & 93.5 & 93.5 & 93.6 & 0.6 \\
\hline $\mathrm{V}_{\mathrm{s}}$ & 5.3 & 5.3 & 5.2 & 5.0 & 4.8 & 4.6 & 4.6 & 4.7 & - \\
\hline $\mathrm{D}$ & 1.3 & 1.2 & 1.2 & 1.2 & 1.2 & 1.2 & 1.2 & 1.2 & - \\
\hline $\mathrm{R}$ & 19.7 & 19.4 & 18.9 & 18.8 & 18.2 & 17.6 & 17.3 & 17.4 & - \\
\hline K1 & 86.4 & 86.9 & 86.7 & 87.3 & 87.7 & 88.1 & 87.8 & 87.7 & - \\
\hline M & 91.4 & 90.6 & 91.1 & 91.2 & 91.5 & 90.7 & 90.7 & 90.7 & - \\
\hline K3 & 93.0 & 93.2 & 93.5 & 93.3 & 94.2 & 93.9 & 93.7 & 93.7 & - \\
\hline $\mathrm{A}_{\mathrm{s}}$ & -0.7 & -0.6 & -0.5 & -0.5 & -0.5 & -0.3 & -0.2 & -0.1 & - \\
\hline $\mathrm{K}$ & 0.0 & -0.2 & -0.5 & -0.3 & -0.3 & -0.4 & -0.5 & -0.6 & - \\
\hline
\end{tabular}

* Key: $y_{\min }$ - minimum value for the country, $y_{\max }$-maximum value for the country, $\mathrm{V}_{\mathrm{s}}$-coefficient of variation in \% for EU (28) countries,

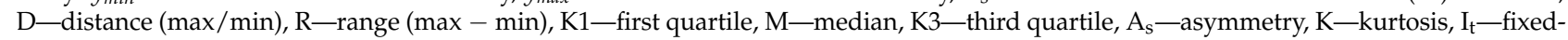
base index $\mathrm{I}_{\mathrm{t}}(2017 / 2010 \times 100-100)$ in \%. Source: own work based on [16]. 
According to data from 2010-2017, the EU Member State that emitted the most ammonia from agricultural activities was Ireland. The value of the $\mathrm{Y}_{01 \mathrm{~B}}$ indicator in 2017 for this country was $99.1 \%$. In Ireland, ammonia emissions from agriculture are the highest, and in recent years (2010-2017), they have further increased by $0.8 \%$ (in 2010, emissions of this gas amounted to $98.3 \%$ ). The country that emitted relatively the least ammonia from agriculture was Portugal. The ammonia emissions for this country in 2017 were $81.7 \%$, and compared to 2010, they increased significantly (by as much as 3.9\%). In Poland, the share of ammonia emissions from agriculture as a percentage of total emissions in 2017 was slightly above the average for EU countries and amounted to $93.6 \%$. Poland also saw a slight increase in emissions by $0.6 \%$ compared to 2010. Apart from Ireland, the countries where agriculture accounted for the largest share of nitrogen emissions in the percentage of total emissions were Cyprus (96.7\%), Malta (95.7\%), and Germany $(95.0 \%)$, while the aforementioned countries such as Portugal $(81.7 \%)$, Bulgaria $(84.0 \%)$, Croatia $(84.6 \%)$, and Latvia $(85.0 \%)$ were on the other extreme of the ranking (Table 3 and Figure 3 ).

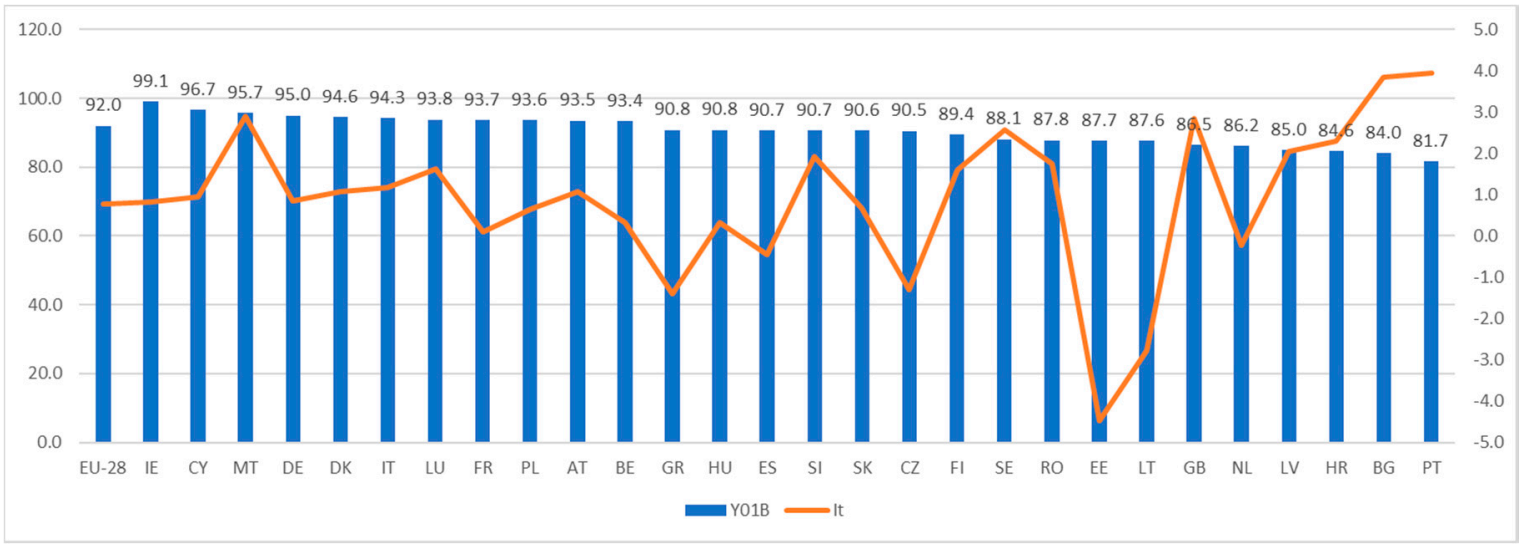

Figure 3. Ammonia $\left(\mathrm{NH}_{3}\right)$ emissions from agriculture- $\%$ of total emissions $\mathrm{Y}_{01 \mathrm{~B}}$ in EU countries (28) in 2017 and the fixed-based index $\mathrm{I}_{t}$ (of increase or decrease) of emissions in 2017; base year, $2010=100$. Source: own work based on [16].

The variation between EU Member States in the studied indicator $\mathrm{Y}_{01 \mathrm{~B}}$ in all analysed years of 2010-2017 did not exceed $V_{s}=10 \%$ (maximum $V_{s}=5.3 \%$ in 2010, minimum $V_{s}=$ $4.7 \%$ in 2017); therefore, it can be concluded that EU countries do not differ significantly in terms of ammonia emissions from agriculture as a percentage of total emissions of this gas to the environment, which means that the share of countries in the pollution of air, soil, and water by this harmful gas as a result of agricultural production in rural areas is similar. Based on the conducted analyses and the calculated coefficient of variation $\left(\mathrm{V}_{\mathrm{s}}\right)$, it can be concluded that the level of ammonia emissions from agriculture in the period of 2010-2017 was levelling out, and the already small variation between the countries in this respect was decreasing (Table 3).

The high level of the analysed indicator $\mathrm{Y}_{01 \mathrm{~B}}$ in 2017 was caused, inter alia, by its increase since 2010 in most Member States. Only six countries noted a decrease in ammonia emissions between 2010 and 2017: Estonia $(-4.5 \%)$, Lithuania $(-2.8 \%)$, Greece $(-1.4 \%)$, and the Czech Republic $(-1.3 \%)$, with a slight decrease in Spain $(-0.4 \%)$ and the Netherlands $(-0.2 \%)$. The remaining 22 countries saw an increase in ammonia emissions from agriculture since 2010, which was the highest in Bulgaria $(+3.8 \%)$ and Portugal (+3.9\%) (Figure 4$)$.

The calculated asymmetry (skewness) coefficients (A), which were negative, and histograms for the dependent variable $\mathrm{Y}_{01 \mathrm{~B}}$ indicate a left-skewed distribution. The low negative value of kurtosis, which is a measure of tailedness of the distribution of objects, indicates a low concentration of groupings (countries, studied objects) around the average value, which means that the countries are extensively scattered and poorly concentrated around the EU average (Table 3 and Figure 5). 


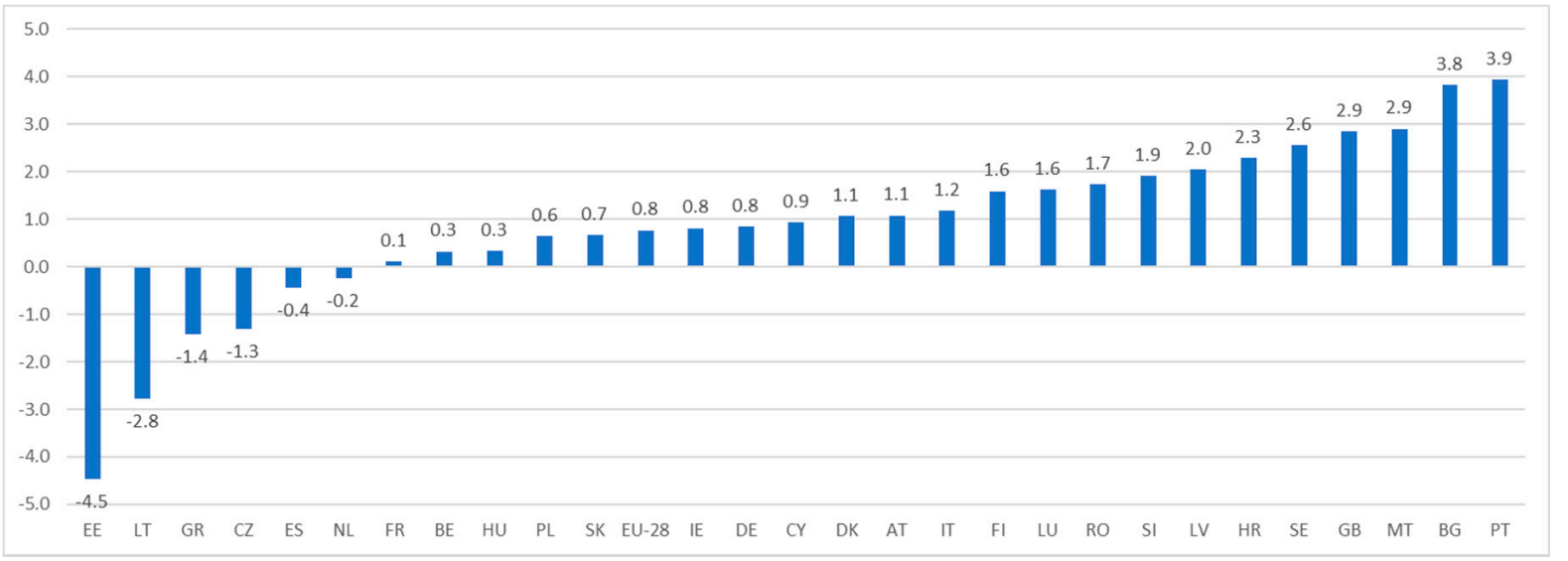

Figure 4. Fixed-base index $\mathrm{I}_{\mathrm{S}}$ calculated for the variable $\mathrm{Y}_{01 \mathrm{~B}}$-ammonia $\left(\mathrm{NH}_{3}\right)$ emissions from agriculture-\% of total emissions in EU countries (28) in 2017; base year, 2010 = 100. Source: own work based on [16].
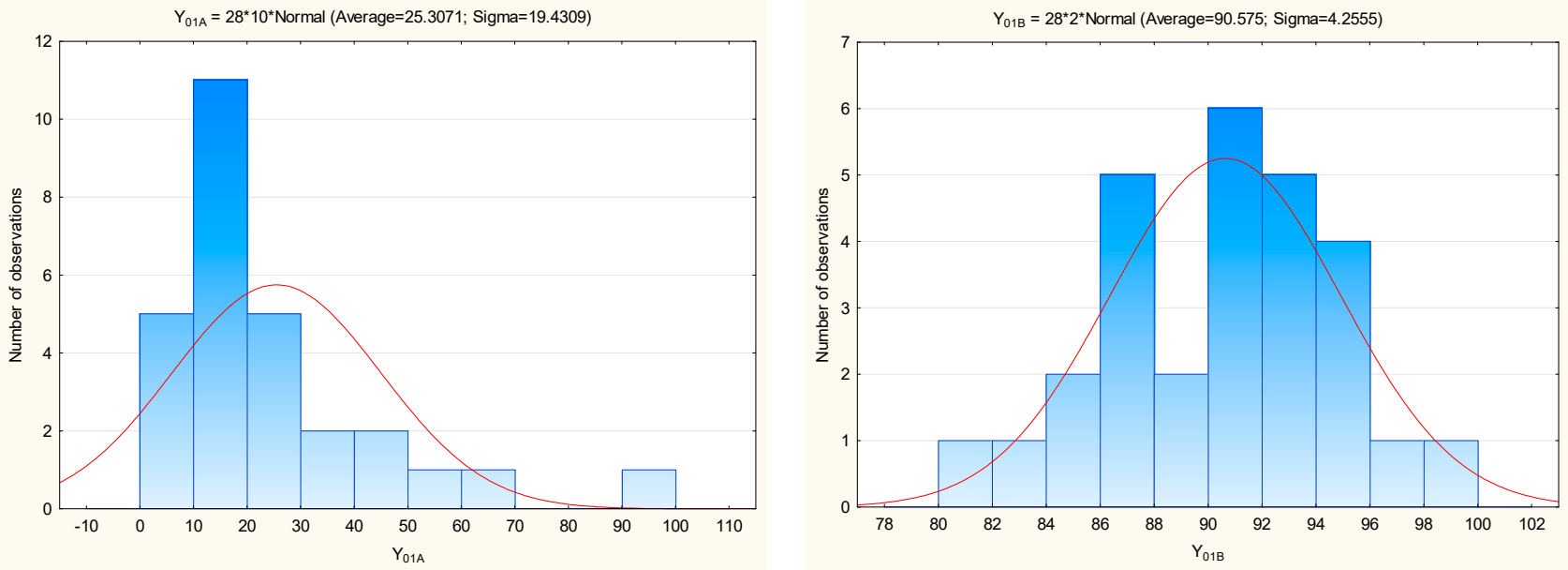

Figure 5. Histograms for the dependent variables $\mathrm{Y}_{01 \mathrm{~A}}$ and $\mathrm{Y}_{01 \mathrm{~B}}$ describing the levels of ammonia emissions by EU countries (28) in 2017. Source: own work based on [16].

On the basis of the correlation analyses performed, it was confirmed that there is a positive correlation, $\mathrm{r}_{\mathrm{y} 01 \mathrm{Ay} 01 \mathrm{~B}}=0.472$, between nitrogen emissions from agriculture in kilograms per hectare of utilised agricultural area $\left(\mathrm{Y}_{01 \mathrm{~A}}\right)$ and nitrogen emissions from agriculture as a percentage of total emissions of this gas. Therefore, it follows that these indicators describe the level of ammonia emissions by EU countries in a similar way. On the other hand, there are no significant correlation relationships between the indicators describing ammonia emissions and the $\mathrm{I}_{t}$ dynamic indices (Table 4). The lack of correlation between $\mathrm{Y}_{01 \mathrm{~A}}$ and $\mathrm{I}_{\mathrm{t} Y 01 \mathrm{~A}}$, as well as $\mathrm{Y}_{01 \mathrm{~B}}$ and $\mathrm{I}_{\mathrm{tY}} \mathrm{O1B}$, confirmed the results obtained earlier concerning the differences in the behaviour of the countries with respect to ammonia emission reductions. It can be unambiguously stated that countries with high ammonia emissions from agriculture did not emit increasingly less of it since 2010; on the contrary, the relative increase was higher compared to other countries; for instance, such a situation was observed in countries such as Austria, Luxembourg, or the Netherlands. Meanwhile, some countries with relatively low ammonia emissions from agriculture still reduced their emissions even more. Such countries were, for example, Slovakia, Estonia, Lithuania, and Greece (Table 4). 
Table 4. Correlations $r_{x y}$ between variables characterising ammonia emissions $\mathrm{Y}_{01 \mathrm{~A}}$ and $\mathrm{Y}_{01 \mathrm{~B}}$ and the fixed-based indices $\mathrm{I}_{\mathrm{t}}$ for $2017(2010=100)$ in EU countries $(28)$ in 2017.

\begin{tabular}{ccccc}
\hline Variable & $\mathbf{Y}_{\mathbf{0 1 A}}$ & $\mathbf{Y}_{\mathbf{0 1 B}}$ & $\mathbf{I}_{\mathbf{t Y 0 1 A}}$ & $\mathbf{I}_{\mathbf{t} \text { Y01B }}$ \\
\hline $\mathrm{Y}_{01 \mathrm{~A}}$ & 1.000 & $0.472{ }^{*}$ & -0.194 & 0.157 \\
\hline $\mathrm{Y}_{01 \mathrm{~B}}$ & $0.472{ }^{*}$ & 1.000 & 0.001 & -0.171 \\
\hline $\mathrm{I}_{\mathrm{t} \text { 01A }}$ & -0.194 & 0.001 & 1.000 & 0.196 \\
\hline $\mathrm{I}_{\mathrm{tY01B}}$ & 0.157 & -0.171 & 0.196 & 1.000 \\
\hline
\end{tabular}

* The correlation coefficients marked by an asterisk are significant with $p<0.05000 ; \mathrm{N}=28$ (missing data was deleted on a case-to-case basis). Source: own work based on [16].

The additional aim of the study was to determine whether there is a correlation between economic conditions and the level of ammonia emissions from agriculture in EU countries. Three independent variables were considered as the economic factors. The first variable was $\mathrm{X}_{01}$-government appropriations or outlays to support agricultural research and development (R\&D) in EUR per capita, the second was $\mathrm{X}_{02}$-agricultural factor income in EUR per annual work unit (AWU), and the third was $\mathrm{X}_{03}$-real GDP per capita in EUR. The first two variables characterised economic factors related to agriculture, whereas the third indicator was a basic measure of the level of economic development and living standards in a country. There is a positive significant correlation between all independent indicators $X\left(r_{X_{01} \times 02}=0.431, r_{X 01 \times 03}=0.403, r_{X 03 \times 02}=0.612\right)$, which means that they convey the same or similar information about a country and its position in the ranking. Highly developed countries also had high labour productivity in the agricultural sector and government support to agricultural research and development (Table 5).

Table 5. Correlations $r_{x y}$ between independent variables $X_{01}, X_{02}$, and $X_{03}$ characterising economic conditions of ammonia emissions from agriculture in EU (28) countries in 2017.

\begin{tabular}{cccc}
\hline Variable & $\mathbf{X}_{\mathbf{0 1}}$ & $\mathbf{X}_{\mathbf{0 2}}$ & $\mathbf{X}_{\mathbf{0 3}}$ \\
\hline $\mathrm{X}_{01}$ & 1.000 & $0.431^{*}$ & $0.403^{*}$ \\
\hline $\mathrm{X}_{02}$ & $0.431^{*}$ & 1.000 & $0.612^{*}$ \\
\hline $\mathrm{X}_{03}$ & $0.403^{*}$ & $0.612^{*}$ & 1.000 \\
\hline
\end{tabular}

* The correlation coefficients marked by an asterisk are significant with $p<0.05000 ; \mathrm{N}=28$ (missing data was deleted on a case-to-case basis). Source: own work based on [16].

As Table 6 shows, there are positive correlations between the economic variables $X_{01}$, $\mathrm{X}_{02}, \mathrm{X}_{03}$ and the variable $\mathrm{Y}_{01 \mathrm{~A}}$ but the values of the correlation coefficient $\mathrm{r}_{\mathrm{xy}}$ are too low

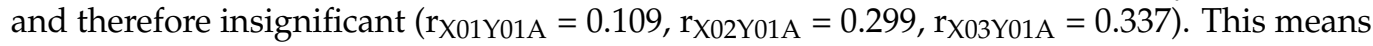
that the economic level of a country, labour productivity in the agricultural sector, and the level of support to agricultural research and development do not have a significant impact on the level of ammonia emissions from agriculture measured as kilograms per hectare of utilised agricultural area.

Table 6. Correlations $r_{x y}$ between the independent variables $X_{01}, X_{02}$ and $X_{03}$ and the dependent variables $Y_{01 \mathrm{~A}}$ and $\mathrm{Y}_{01 \mathrm{~B}}$ (data for EU countries (28) in 2017).

\begin{tabular}{cccc}
\hline Variable & $\mathbf{X}_{\mathbf{0 1}}$ & $\mathbf{X}_{\mathbf{0 2}}$ & $\mathbf{X}_{\mathbf{0 3}}$ \\
\hline $\mathrm{Y}_{01 \mathrm{~A}}$ & 0.109 & 0.299 & 0.337 \\
\hline $\mathrm{Y}_{01 \mathrm{~B}}$ & $0.467^{*}$ & 0.219 & $0.456^{*}$ \\
\hline
\end{tabular}

* The correlation coefficients marked by an asterisk are significant with $p<0.05000 ; \mathrm{N}=28$ (missing data was deleted on a case-to-case basis). Source: own work based on [16]. 
The conclusion is different for the indicator measuring ammonia emissions from agriculture- the percentage of total emissions $\left(\mathrm{Y}_{01 \mathrm{~B}}\right)$. An investigation of the most recent available data from 2017 revealed that there are significant positive correlations between ammonia emissions measured in this way and the economic conditions $\mathrm{X}_{01}$ and $\mathrm{X}_{03}\left(\mathrm{r}_{\mathrm{X} 01 \mathrm{Y} 01 \mathrm{~B}}=0.467\right.$ and $\left.\mathrm{r}_{\mathrm{X} 03 \mathrm{Y} 01 \mathrm{~B}}=0.456\right)$. Therefore, it can be stated that in EU countries, there is a significant relationship between ammonia emissions from agriculture as a percentage of total emissions and the economic development of the country as measured in GDP per capita. The richer the country and the higher the level of its economic development, the more ammonia it emits from agriculture as a percentage of total emissions. The same applies to the link between the share of ammonia emissions from agriculture and government support to agricultural research and development. Countries that emit significantly more ammonia from agriculture to the environment at the same time incur significantly higher agricultural research and development expenditure. In contrast, no link has been demonstrated between ammonia emissions from agriculture as a percentage of total emissions $\mathrm{Y}_{01 \mathrm{~B}}$ and $\mathrm{X}_{02}$-a measure of labour productivity in the agricultural sector $\left(\mathrm{r}_{\mathrm{X} 02 \mathrm{Y} 01 \mathrm{~B}}=0.219\right)($ Table 6$)$.

The scatter plot (Figure 6) and the results of the regression analysis (Table 7) confirm the conclusions obtained on the basis of the correlation analysis between the $\mathrm{Y}_{01 \mathrm{~B}}$ and $\mathrm{X}_{03}$ indices. However, it should be noted that the correlation values, although significant, in the case of the $\mathrm{Y}_{01 \mathrm{~B}}$ indicator do not fully explain the impact of the country's GDP per capita on the share of ammonia emissions from agriculture in the total emissions. For example, the coefficient of determination $R^{2}=0.208$ calculated for the variables $Y_{01 B}$ and $\mathrm{X}_{03}$ shows only a $20 \%$ impact of GDP per capita variability $\left(\mathrm{X}_{03}\right)$ on the variability of the share of ammonia emissions from agriculture in the total emissions of this gas $\left(\mathrm{Y}_{01 \mathrm{~B}}\right)$. It, therefore, turns out that all other causal sources (except GDP) had an almost $80 \%$ impact on the level of ammonia emissions from agriculture. Therefore, it is advisable that the regression function of one explanatory variable $\left(\mathrm{X}_{03}\right)$ be transformed into a multiple regression function involving more variables $\left(\mathrm{X}_{01}, \mathrm{X}_{02}, \mathrm{X}_{03}\right)$.

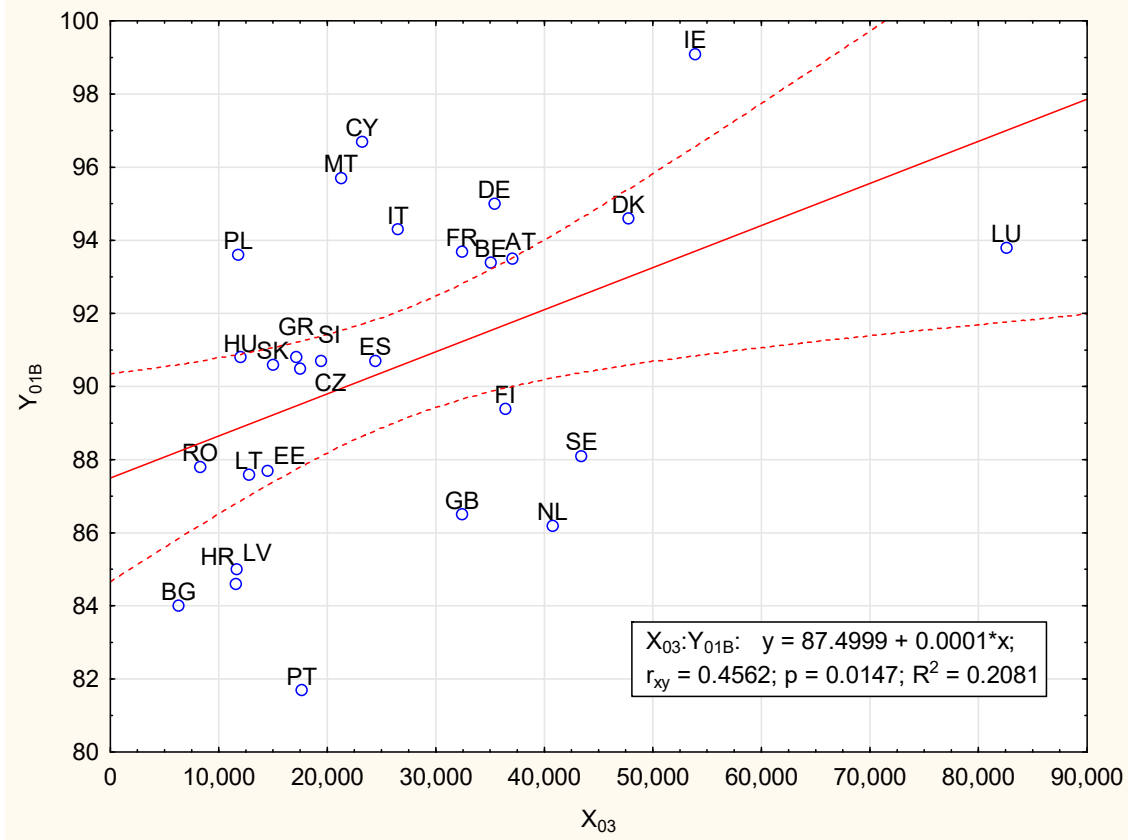

Figure 6. Scatterplots of the dependent variable $\mathrm{Y}_{01 \mathrm{~B}}$ and the independent variable $\mathrm{X}_{03}$ (data for EU countries (28) in 2017). Key: $r_{x y}$-linear correlation coefficient; $R^{2}$ —coefficient of determination. Source: Own work based on [16]. 
Table 7. Summary of regression of dependent variable $\mathrm{Y}_{01 \mathrm{~B}}$ with independent variable $\mathrm{X}_{03}$ (data for EU countries (28) in 2017).

Summary of Dependent Variable Regression: $\mathrm{Y}_{01 \mathrm{~B}} ; \mathrm{r}_{\mathrm{xy}}=0.456, \mathrm{R}^{2}=0.208$

Corrected $\mathrm{R}^{2}=0.178 ; \mathrm{F}(1.26)=6.8333, p<0.0147$ Standard Error of Estimation (SEE): 3.859

\begin{tabular}{cccccccc}
\hline $\mathbf{N}=\mathbf{2 8}$ & $\mathbf{b}^{*}$ & SEE from $\mathbf{b}$ & $\mathbf{b}$ & SEE from $\mathbf{b}$ & $\mathbf{t}(\mathbf{2 6})$ & $\boldsymbol{p}$ \\
\hline Free word & & & 87.500 & 1.384 & 63.219 & 0.000 \\
\hline $\mathbf{X}_{\mathbf{0 3}}$ & 0.456 & 0.175 & 0.000 & 0.000 & 2.614 & 0.015 \\
\hline
\end{tabular}

Key: $\mathrm{r}_{\mathrm{xy}}$-linear correlation coefficient; $\mathrm{R}^{2}$ —coefficient of determination; $\mathrm{F}$ - F statistics; $\mathrm{t}$-Student's $\mathrm{t}$ statistics; $\mathrm{b}$ - coefficient $\mathrm{b}$ for the independent variable; $b$ *-BETA coefficient (standardized $b$ coefficient); $p$ —critical significance level. Source: own work based on [16].

The results obtained on the basis of multiple regression analysis (Table 8) confirmed the correctness of including more independent variables in the analysis. The correlation coefficient at the level $\mathrm{r}_{\mathrm{xy}}=0.574$ documented a significant impact of economic conditions $\left(\mathrm{X}_{01}, \mathrm{X}_{02}, \mathrm{X}_{03}\right)$ on the level of ammonia emissions from agriculture $\left(\mathrm{Y}_{01 \mathrm{~B}}\right)$. It should be emphasized that the coefficient of determination at the level of $R^{2}=0.329$ indicated an almost $33 \%$ impact of the variability of the economic factors taken into account during the study on the variability of the $\mathrm{Y}_{01 \mathrm{~B}}$ index. However, there were other conditions that account for $67 \%$ of the differences in the level of ammonia emissions from agriculture in the EU countries.

Table 8. Summary of regression of dependent variable $\mathrm{Y}_{01 \mathrm{~B}}$ with independent variables $\mathrm{X}_{01}, \mathrm{X}_{02}$, and $\mathrm{X}_{03}$ (data for EU countries (28) in 2017).

Summary of Dependent Variable Regression: $\mathrm{Y}_{01 \mathrm{~B}} ; \mathrm{r}_{\mathrm{xy}}=0.574 \mathrm{R}^{2}=0.329$;

Corrected $R^{2}=0.245 ; F(3.24)=3.929 p<0.0205$ Standard Error of Estimation (SEE): 3.696

\begin{tabular}{cccccccc}
\hline $\mathbf{N}=\mathbf{2 8}$ & $\mathbf{b}^{*}$ & SEE from $\mathbf{b}^{*}$ & $\mathbf{b}$ & SEE from $\mathbf{b}$ & $\mathbf{t}(\mathbf{2 4})$ & \multicolumn{1}{c}{${ }^{*}$} \\
\hline Free word & & & 87.125 & 1.453 & 59.954 & 0.000 \\
\hline $\mathbf{X}_{\mathbf{0 1}}$ & 0.384 & 0.189 & 0.337 & 0.166 & 2.033 & 0.053 \\
\hline $\mathbf{X}_{\mathbf{0 2}}$ & -0.209 & 0.219 & 0.000 & 0.000 & -0.958 & 0.348 \\
\hline $\mathbf{X}_{\mathbf{0 3}}$ & 0.430 & 0.216 & 0.000 & 0.000 & 1.993 & 0.058 \\
\hline
\end{tabular}

Key: $r_{x y}$-linear correlation coefficient; $R^{2}$ - coefficient of determination; $F$-F statistics; $t$-Student's $t$ statistics; $b$-coefficient $b$ for the independent variable; $b$ * -BETA coefficient (standardized $b$ coefficient); $p$ —critical significance level. Source: own work based on [16].

\section{Discussion}

The concept of sustainable development, defined as a set of activities aimed at meeting the basic needs of the population while preserving natural resources for future generations [56], has emerged in response to the increasingly dangerous interference of humans with the natural environment. In European Union states, air pollution concerns are an extremely important element of policy on environmental protection and the protection of human health and life.

An endangerment risk reduction approach is one of the priorities of modern economies. Highly developed countries have a significant share of the emissions of harmful pollutants [57]. Economic growth is still a priority for most economies in the world, including the European Union Member States. Those states operate according to a model of a linear economy, which entails a risk for society as a result of the degradation of the natural environment. The hope for a change in this situation is the transformation of linear economies into circular economies. In addition, gradual actions of countries to reduce the burden on the natural environment are continuously initiated and undertaken [58].

The impact of economic conditions, especially economic growth, on the emissions of harmful gases into the environment has been studied by many authors. In the literature, we can find studies verifying the hypothesis of the environmental Kuznets curve (EKC) [59], about the inverted U-shaped relationship between GDP per capita and greenhouse gas 
emissions, or other indicators describing environmental degradation [60-62]. It turns out that the significance of the relationship between the economic growth of countries and the emissions of harmful gases depends on whether they are long-term or short-term studies $[60,63]$. The analyses of some researchers have confirmed the hypothesis of the Kuznets curve (EKC) $[62,64,65]$, while it has been contradicted by others [61].

The above-mentioned authors have most often pointed to economic growth as the cause of harmful gas emissions, while other researchers have treated a certain level of economic development in the future as a result of the current impact of industry and agriculture on environmental degradation [66]. Ziolo et al. [67] also dealt with the problem of the relationship between environmental effects and economic and financial development in the EU countries. They found that the link between financial sustainability and environmental degradation is more relevant in converged economies than in developed countries but increases in developed countries and reduces greenhouse gas emissions in converged economies.

Agriculture today, like any other production activity, poses a real threat to the environment, and the release of pollutants into the atmosphere from agricultural sources is a major environmental and economic issue. The idea of sustainable rural development addresses environmental risks and social concerns, especially in highly developed countries [68,69]. The significant impact of the level of agricultural potential on the natural environment has also been confirmed by other authors [70,71]. Countries with a high level of agricultural potential, characterised, inter alia, by high land productivity and a favourable agrarian structure, exert stronger pressure on the environment. In contrast, countries with weaker agricultural pressure on the environment are also characterised by low and medium agricultural potential with a sub-optimal agrarian structure, significantly deviating from the EU average in terms of land productivity and yields.

Therefore, as the literature rightly emphasises, a considerable intensification and concentration of agricultural production combined with a high level of fertilisation and a significant stocking density (e.g., in the Netherlands and Belgium) may entail many adverse environmental consequences [72], primarily in the form of ammonia emissions. Similar challenges are relevant for other European countries, including Poland [28], as well as other countries also located in the Baltic Sea region [3]. The authors pointed out that the characteristic features and potential of agriculture in a given country have a significant impact on the emission of harmful gases, and therefore, it would be advisable to further study the diversity and strength of the relationship between these phenomena in the EU countries.

In summary, most empirical research focuses on using aggregated data to investigate levels and trends of harmful gas emissions and the relationship between emissions and economic development or other economic factors. Some of these studies use time series data for different time periods that are known to give unbelievable and inconsistent results. Researchers also take into account different groups of countries (regions) for research. Then conclusions are drawn, for example, for European countries [62,64], the Middle East and South Asia [61,63], Tunisia [60] or others [65], and it is commonly known that these regions differ from each other in terms of economic development and the potential of agriculture. Therefore, as indicated above, there are many studies on this issue, but the obtained results are inconsistent and varied, which show difficulties in comparing the obtained results and conclusions.

\section{Conclusions}

Agriculture in Europe plays an important part as an emitter of ammonia, and in recent years the adverse impact of this sector of the economy on the degradation of the natural environment has escalated even further. On the basis of the present study, it may be unambiguously concluded that there has been no progress in the sustainable management of emissions of this gas by European Union countries. In 2017, compared to the situation eight years earlier (2010), the emissions of ammonia resulting from agricultural production 
according to the $\mathrm{Y}_{01 \mathrm{~A}}$ indicator (in kilograms per hectare of the utilised agricultural area) increased by as much as $3.6 \%$, and by $0.8 \%$ according to the $\mathrm{Y}_{01 \mathrm{~B}}$ indicator (percentage of total emissions). Between 2010 and 2017, every year, agriculture in the EU was responsible for as much as $92 \%$ of total ammonia emissions, making the subsequent and successive increase in emissions of this gas in EU countries disturbing. In 2010-2017, the largest share of ammonia emissions from agriculture in total emissions of this gas was recorded in Ireland, Cyprus, Malta, and Germany, and the smallest in Portugal, Bulgaria, and Croatia. Emissions of this gas in Poland are close to the EU average.

The analyses have shown that EU countries do not vary significantly in terms of the share of ammonia emissions from agriculture in percentage of total emissions. The countries with the lowest $Y_{01 \mathrm{~B}}$ figures are still responsible for more than $80 \%$ of total ammonia emissions from agriculture. Emissions of ammonia from agriculture in Poland, both in percentage of total emissions and in kilograms per hectare of utilised agricultural area, remain at a level similar to the EU average. In Poland, as in most EU countries, ammonia emissions increased as well. The greatest impact on this change has been predominantly attributed to the increase in the use of mineral fertilisers as well as natural fertilisers related to livestock farming [18], mainly manure management in dairy cow and pig farming $[9,73]$.

With such a high share of agriculture in ammonia emissions $\left(\mathrm{Y}_{01 \mathrm{~B}}\right)$, one could expect action from EU Member States, and consequently, a downward trend in emissions of this gas over the last years 2010-2017 ( $\left.\mathrm{I}_{\mathrm{t} Y 01 \mathrm{~B}}\right)$. However, the analyses performed have not confirmed such a causal link. It turns out, for example, that in recent years, countries with high ammonia emissions from agriculture have produced even more ammonia (e.g., Austria and Luxembourg), while some countries with low ammonia emissions from agriculture have reduced emissions of this gas (e.g., Slovakia, Estonia, and Lithuania).

Countries with high economic development and high levels of economic indicators characterising agriculture emit most ammonia from agriculture. This was confirmed by the correlation and regression analysis between the independent variables $X_{01}, X_{02}$, and $X_{03}$ and the dependent variables $\mathrm{Y}_{01 \mathrm{~A}}$ and $\mathrm{Y}_{01 \mathrm{~B}}$. Correlation values determining the existence of a link between the variable $\mathrm{Y}_{01 \mathrm{~A}}$ and the economic conditions were found to be positive but too low to recognise the significance of the link. However, the $X_{01}, X_{02}$, and $X_{03}$ variables and the $\mathrm{Y}_{01 \mathrm{~B}}$ variable have actually shown both positive and significant correlations. Hence, it may be clearly stated that the richer and more economically developed an EU Member State is, the more ammonia from agriculture it emits. It also turns out that significantly more frequently, the share of agriculture in ammonia emissions is greater in countries that incur relatively higher expenditure on agricultural research and development compared with other countries. It should also be emphasized that economic factors, such as GDP per capita, government expenditure on research and development in agriculture and labour productivity in agriculture, only in less than $33 \%$ affect the share of ammonia emissions from agriculture, while all other factors not taken into account during the study (determinants) had a $67 \%$ impact on the level of emissions of this gas from agriculture in terms of total ammonia emissions.

The increase in ammonia emissions from the agricultural sector in the European Union countries, which have been progressing since 2010, may constitute a significant impediment to the achievement of reduction targets resulting from the Directive of the European Parliament and of the Council of 14 December 2016 on the reduction of national emissions of certain atmospheric pollutants (NEC Directive) and other documents [45-48,74]. At the current stage of economic development of EU Member States, actions to protect the rural environment should be one of the basic forms of initiating the necessary changes in agriculture, especially in livestock production. In the overall economic policy of the European Union, environmental issues are becoming extremely important and must be attended to rigorously. Limiting ammonia emissions from agriculture by all Member States is essential in order to meet the requirements of the NEC Directive.

The results of the presented research indicate the existence of differences in the level of ammonia emissions from agriculture in individual EU countries and the dependence 
between the economic development of these countries and emission levels. The work may contribute to the continuation of the discussion on these issues among scientists, as well as a wide range of stakeholders who decide on the future directions of agricultural development.

The authors plan to continue the analysis of ammonia emissions from agriculture in the EU countries in the longer term and to expand the scope of the analysed indicators affecting the phenomenon. In this article, among the independent indicators, three economic factors were taken into account, describing the level of economic development of the studied countries (GDP per capita), the level of state expenditure on research and development in agriculture, and the income obtained from agricultural activities (labour productivity in agriculture). In the future, the authors plan to expand their research on other factors among the independent variables, such as the size of farms, intensification of agricultural production, and the levels of food exports.

Author Contributions: Conceptualization, A.M. and P.P.; methodology, A.M. and P.P.; software, A.M. and P.P.; validation, A.M. and P.P.; formal analysis, A.M. and P.P.; investigation, A.M. and P.P.; resources, A.M. and P.P.; data curation, A.M. and P.P.; writing-original draft preparation, A.M. and P.P.; writing—review and editing, A.M. and P.P.; visualization, A.M. and P.P.; supervision, A.M. and P.P.; project administration, A.M. and P.P.; funding acquisition, A.M. and P.P. All authors have read and agreed to the published version of the manuscript.

Funding: This research received no external funding.

Institutional Review Board Statement: Not applicable.

Informed Consent Statement: Not applicable.

Data Availability Statement: Not applicable.

Conflicts of Interest: The authors declare no conflict of interest.

\section{References}

1. World Meteorological Organization. Statement on the State of the Global Climate in 2019; WMO-No. 1248; World Meteorological Organization: Geneva, Switzerland, 2020. Available online: https://library.wmo.int/doc_num.php?explnum_id=10211 (accessed on 4 November 2020).

2. European State of Climate (ESOTC). European Commission, Copernicus, ECMWF. 2019. Available online: https://climate. copernicus.eu/ESOTC/2019 (accessed on 4 November 2020).

3. Storch, H.; Omstedt, A.; Pawlak, J.; Reckermann, M. Second Assessment of Climate Change for the Baltic Sea Basin. Introduction and Summary. In Regional Climate Studies; Bolle, H.-J., Menenti, M., Vesuvio, S.S., Rasool, S.I., Eds.; Springer: Cham, Switzerland, 2015; p. 16.

4. Murawska, A. Tendencje zmian wzorców konsumpcji w krajach Unii Europejskiej w kierunku zrównoważonego rozwoju (Trends in Consumption Patterns in European Union Countries Towards Sustainable Development). J. Agribus. Rural Dev. 2015, 3, 477-485. [CrossRef]

5. Murawska, A. Marnowanie Żywności-Wspólny Problem (Food Waste-A Common Problem). Format 2.0; Magazyn Uniwersytetu Technologiczno-Przyrodniczego w Bydgoszczy: Bydgoszcz, Poland, 2019; pp. 26-29.

6. Głodowska, M.; Gałązka, A. Intensyfikacja rolnictwa a środowisko naturalne (Unsustainable agriculture and its environmental consequences). Zesz. Probl. Postępów Nauk Rol. 2018, 592, 3-13. [CrossRef]

7. Jadczyszyn, T.; Kopiński, J. Produkcyjne i Środowiskowe Aspekty Nawożenia Azotem (Production and Environmental Aspects of Nitrogen Fertilization); Studia i Raporty; IUNG-PIB (Institute of Soil Science and Plant Cultivation State Research Institute): Puławy, Poland, 2013; Volume 34, pp. 27-45.

8. Rolnictwo w 2018 r. (Agriculture in 2018); Główny Urząd Statystyczny: Warszawa, Poland, 2019; pp. 17-69. Available online: https: //stat.gov.pl/obszary-tematyczne/rolnictwo-lesnictwo/rolnictwo/rolnictwo-w-2018-roku,3,15.html (accessed on 4 November 2020).

9. Tian, H.; Xu, R.; Canadell, J.G.; Thompson, R.L.; Winiwarter, W.; Suntharalingam, P.; Yao, Y. A comprehensive quantification of global nitrous oxide sources and sinks. Nature 2020, 586, 248-256. [CrossRef] [PubMed]

10. Schläpfer, F. External Costs of Agriculture Derived from Payments for Agri-Environment Measures: Framework and Application to Switzerland. Sustainability 2020, 12, 6126. [CrossRef]

11. Rolnictwo i Gospodarka Żywnościowa w Polsce (Agriculture and Food Economy in Poland). Praca Zbiorowa Pod Red. IERiGŻ; Ministerstwo Rolnictwa i Rozwoju Wsi: Warszawa, Poland, 2019; p. 22. Available online: https://www.gov.pl/web/rolnictwo/rolnictwo-igospodarka-zywnosciowa-w-polsce (accessed on 4 November 2020).

12. Connelly, N.G.; Damhus, T.; Hartshorn, R.M.; Hutton, A.T. Nomenclature of Inorganic Chemistry; IUPAC Recommendations 2005 (Red Book); International Union of Pure and Applied Chemistry; RSC Publishing: Cambridge, UK, 2005 ; p. 314. 
13. Pietrzak, S. Dobre Praktyki w Zakresie Ograniczania Emisji Amoniaku z Nawozów (Good Practices for Reducing Ammonia Emissions from Fertilizers); Instytut Melioracji i Użytków Zielonych w Falentach, Zakład Ochrony Jakości Wody: Falenty, Poland, 2009; pp. 1-17.

14. Marcinkowski, T. Emisja gazowych związków azotu z rolnictwa (The emission of gaseous nitrogen compounds from agriculture). Woda Środowisko Obszary Wiejskie 2010, 10, 175-189.

15. Faber, A.; Jarosz, Z.; Żyłowski, T. Verification of the Possibilities to Reduce Ammonia Emission for Various Slurry Application Practices in Poland. Probl. World Agric. 2019, 19, 31-40. [CrossRef]

16. Eurostat. Your Key to European Statistics. 2020. Available online: https:/ / ec.europa.eu/eurostat/data/database (accessed on 30 October 2020).

17. Sapek, A. Emisja amoniaku z rolnictwa w Polsce (Emission of ammonia from agriculture in Poland). Zagadnienia Ekonomiki Rolnej 2013, 2, 114-123.

18. Krajowy Bilans Emisji SO2, NOX, CO, NH3, NMLZO, Pyłów, Metali Ciężkich i TZO za Lata 2015-2017 w Układzie Klasyfikacji SNAP. Raport Syntetyczny (National Emission Balance of $\mathrm{SO}_{2}, \mathrm{NOX}, \mathrm{CO}, \mathrm{NH}_{3}, \mathrm{NMLZO}$, Dust, Heavy Metals and TZO for 2015-2017 in the SNAP Classification System. Synthetic Report); Krajowy Ośrodek Bilansowania i Zarzadzania Emisjami (KOBIZE) Instytut Ochrony Środowiska_Państwowy Instytut Badawczy (IOŚ-PIB): Warszawa, Poland, 2019; p. 11. Available online: https://www. kobize.pl/uploads/materialy/materialy_do_pobrania/krajowa_inwentaryzacja_emisji/Bilans_emisji_za_2017.pdf (accessed on 6 November 2020).

19. Ni, J.-Q.; Cortus, E.L.; Heber, A.J. Improving Ammonia Emission Modeling and Inventories by Data Mining and Intelligent Interpretation of the National Air Emission Monitoring Study Database. Atmosphere 2011, 2, 110-128. [CrossRef]

20. Marcinkowski, T.; Kierończyk, M. Emisja amoniaku z wybranych nawozów naturalnych i mineralnych (Ammonia emission from selected organic natural and mineral fertilizers). Zeszyty Problemowe Postępów Nauk Rolniczych 2006, 2, 411-417.

21. Mielcarek, P. Weryfikacja wartości współczynników emisji amoniaku i gazów cieplarnianych z produkcji zwierzęcej (Verification of emission coefficients of ammonia and greenhouse gases from livestock production). Inżynieria Rolnicza 2012, 4, $267-276$.

22. Kodeks Doradczy Dobrej Praktyki Rolniczej Dotyczacy Ograniczenia EMISJI Amoniaku (Advisory Code of Good Agricultural Practice for Reducing Ammonia Emissions); ITP (Institute of Technology and Life Sciences) in Falenty (Ed.) Ministerstwo Rolnictwa i Rozwoju Wsi: Warszawa, Poland, 2019; pp. 9, 13-75. Available online: https:/ /www.gov.pl/attachment/4d85f4d1-65f7-4734-a80f-816d2 bafbe73 (accessed on 9 November 2020).

23. Liu, Z.; Liu, Y.; Murphy, J.P.; Maghirang, R. Ammonia and Methane Emission Factors from Cattle Operations Expressed as Losses of Dietary Nutrients or Energy. Agriculture 2017, 7, 16. [CrossRef]

24. Sepperer, T.; Tondi, G.; Petutschnigg, A.; Young, T.M.; Steiner, K. Mitigation of Ammonia Emissions from Cattle Manure Slurry by Tannins and Tannin-Based Polymers. Biomolecules 2020, 10, 581. [CrossRef] [PubMed]

25. Pietrzak, S. Metoda inwentaryzacji emisji amoniaku ze źródeł rolniczych w Polsce i jej praktyczne zastosowanie (Inventory method for ammonia emissions from agricultural sources in Poland and its practical application). Woda Środowisko Obszary Wiejskie 2006, 6, 319-334.

26. Kuczyński, T.; Dämmgen, U.; Klimont, Z.; Kres-Tomczak, K.; Myczko, A.; Słobodzian-Ksenicz, O. Ammonia emissions in Poland: Inventory projections, uncertainties. In Emissions from European Agriculture; Kuczyński, T., Dämmgen, U., Webb, J., Myczko, A., Eds.; Wageningen Academic Publishers: Wageningen, The Netherlands, 2005; pp. 217-230. [CrossRef]

27. Chadwick, D.R. Emissions of ammonia, nitrous oxide and methane from cattle manure heaps: Effect of compaction and covering. Atmos. Environ. 2005, 39, 787-799. [CrossRef]

28. Kierończyk, M.; Marcinkowski, T. Gospodarstwo rolne jako źródło emisji amoniaku (The farms as a main source of ammonia in the atmosphere). J. Civil Eng. Environ. Archit. JCEEA 2015, 62, 233-241.

29. Hutchings, N.J.; Sommer, S.G.; Andersen, J.M.; Asman, W.A.H. A detailed ammonia emission inventory for Denmark. Atmos. Environ. 2001, 35, 1959-1968. [CrossRef]

30. Sapek, A. Emisja amoniaku z produkcji rolnej (Emission of ammonia from agricultural production). Postępy Nauk Rolniczych 1995, 2,3-23.

31. Kierończyk, M. Analiza wybranych czynników kształtujących emisję amoniaku podczas przechowywania obornika w warunkach eksploatacyjnych (Analysis of selected factors affecting ammonia emission during storage of farmyard manure under exploitation conditions). Woda Środowisko Obszary Wiejskie 2012, 12, 93-102.

32. Jugowar, J.L.; Mielcarek, P.; Rzeźnik, W. Niskoemisyjne techniki aplikacji nawozów naturalnych (Low-emission techniques for the application of natural fertilizers). In Kodeks Doradczy Dobrej Praktyki Rolniczej Dotyczacy Ograniczenia Emisji Amoniaku (Advisory Code of Good Agricultural Practice for Reducing Ammonia Emissions); ITP (Institute of Technology and Life Sciences) in Falenty, Ed.; Ministerstwo Rolnictwa i Rozwoju Wsi: Warszawa, Poland, 2019; pp. 53-64. Available online: https://www.gov.pl/attachment/ 4d85f4d1-65f7-4734-a80f-816d2bafbe73 (accessed on 9 November 2020).

33. Baltic Slurry Acidification. Interreg Baltic Sea Region. European Regional Development Fund; European Union: Maastricht, The Netherlands. Available online: http:/ / balticslurry.eu/ (accessed on 9 November 2020).

34. European Union. Slurry Acidification Has Wide Benefits. Policy Brief. Baltic Slurry Acidification. Interreg Baltic Sea Region. European Regional Development Fund. Available online: http:/ / balticslurry.eu/wp-content/uploads/2017/01/Policy-Brief-Benefits.pdf (accessed on 9 November 2020).

35. Birkmose, T.; Vestergaard, A. Acidification of slurry in barns, stores and during application: Review of Danish research, trials and experience. In Proceedings of the 15th Ramiran Conference, Versailles, France, 10-13 June 2013. 
36. Kai, P.; Pedersen, P.; Jensen, J.E.; Hansen, M.N.; Sommer, S.G. A whole-farm assessment of the efficacy of slurry acidification in reducing ammonia emissions. Eur. J. Agron. 2008, 28, 148-154. [CrossRef]

37. Kierończyk, M.; Mazur, K.; Barwicki, J.; Wiśniewska, R.; Fligiel, B. Report of Institute of Technology and Life Sciences. Results of ammonia emission in 2017 during field trials on permanent grassland. Final Report of Activity WP4 Field Trials: Methodology, Collection of Results and Partners' Practical Experiences 2016-2018. Available online: http:/ / balticslurry.eu/wp-content/uploads/20 16/06/Report-WP4.pdf (accessed on 9 November 2020).

38. Jarosz, Z.; Faber, A. Ograniczenie emisji amoniaku podczas stosowania nawozów mineralnych (Reduction of ammonia emissions when using mineral fertilizers). In Kodeks Doradczy Dobrej praktyki Rolniczej Dotyczacy Ograniczenia Emisji Amoniaku (Advisory Code of Good Agricultural Practice for Reducing Ammonia Emissions); ITP (Institute of Technology and Life Sciences) in Falenty, Ed.; Ministerstwo Rolnictwa i Rozwoju Wsi: Warszawa, Poland, 2019; pp. 65-74.

39. Skowrońska, M. Straty Amoniaku z Mocznika (Loss of Ammonia from Urea). 2016. Available online: https://nawozy.eu/ wiedza/porady-ekspertow / rosliny / straty-amoniaku-z-mocznika.html (accessed on 11 November 2020).

40. Zaliwski, S. Emisja Gazów Cieplarnianych Przez Rolnictwo (Greenhouse Gas Emissions from Agriculture); Studia i Raporty IUNG-PIB (Institute of Soil Science and Plant Cultivation State Research Institute): Puławy, Poland, 2007; pp. 35-47. [CrossRef]

41. Bittman, S.; Dedina, M.; Howard, C.M.; Oenema, O.; Sutton, M. (Eds.) Options for Ammonia Mitigation: Guidance from the UNECE Task Force on Reactive Nitrogen; Centre for Ecology \& Hydrology (CEH): Edinburgh, UK, 2014. Available online: http:/ / nora.nerc.ac.uk/id/eprint/510206/1/N510206CR.pdf (accessed on 9 November 2020).

42. Bieńkowski, J. Regionalne zróżnicowanie emisji amoniaku w polskim rolnictwie w latach 2005-2007 (Regional differentiation of ammonia emission in Polish agriculture in the years 2005-2007). Fragm. Agron. 2010, 27, 21-31.

43. Siggia, D.; Lasorella, M.V.; Kolte, A.; Rossi, M.; Pawar, A. Performance orientation towords biodiversity impacts of energy crop production on agricultural land use and farmland habitats in Europe. J. Crit. Rev. 2020, 7, 1-6. [CrossRef]

44. Siggia, D.; Lasorella, M.V.; Kolte, A.; Pawar, A. Management of energy production with thermochemical combustion: The case of switchgrass perennial crop in mediterranean environment. J. Crit. Rev. 2020, 7, 1185-1192. [CrossRef]

45. Convention on Long-Range Transboundary Air Pollution. Geneva 1979. Available online: https://www.unece.org/env/lrtap/ welcome.html.html (accessed on 18 November 2020).

46. Directive NEC. Directive (EU) 2016/2284 of the European Parliament and of the Council of 14 December 2016 on the Reduction of National Emissions of Certain Atmospheric Pollutants, Amending Directive 2003/35/EC and Repealing Directive 2001/81/EC (Text with EEA Relevance). Available online: https:// eur-lex.europa.eu/legal-content/EN/TXT/?uri=CELEX\%3A32016L2284 (accessed on 4 November 2020).

47. Commission Implementing Decision (EU) 2017/302 of 15 February 2017 Establishing Best Available Techniques (BAT) Conclusions, under Directive 2010/75/EU of the European Parliament and of the Council, for the Intensive Rearing of Poultry or Pigs. Available online: https: / / eur-lex.europa.eu/legal-content/EN/TXT/?uri=uriserv:OJ.L_.2017.043.01.0231.01.ENG\&toc=OJ:L: 2017:043:FULL (accessed on 4 November 2020).

48. Commission Implementing Decision (EU) 2018/1522 of 11 October 2018 Laying Down a Common Format for National Air Pollution Control Programmes under Directive (EU) 2016/2284 of the European Parliament and of the Council on the Reduction of National Emissions of Certain Atmospheric Pollutants. Available online: https:/ / eur-lex.europa.eu/legal-content/EN/ALL/ ?uri=CELEX\%3A02018D1522-20181012 (accessed on 4 November 2020).

49. IUNG-PIB (Institute of Soil Science and Plant Cultivation State Research Institute) in Puławy. Zbiór Zaleceń Dobrej Praktyki Rolniczej Majacy na Celu Ochronę Wód Przed Zanieczyszczeniem Azotanami Pochodzacymi ze Źródet Rolniczych (A Collection of Good Agricultural Practice Recommendations Aimed at Protecting Waters against Pollution with Nitrates from Agricultural Sources); Ministerstwo Rolnictwa i Rozwoju Wsi: Warszawa, Poland, 2019. Available online: https://sir.cdr.gov.pl/2019/10/16/kodeks-amoniakowy-oraz-zbiorzalecen-dobrej-praktyki-rolniczej-majacej-na-celu-ochrone-wod-przez-zanieczyszeniami-azotanami/zbior_zalecen_dobrej_ praktyki_rolniczej_26022019_egz_bip/(accessed on 6 November 2020).

50. Rozporządzenie Rady Ministrów z Dnia 5 Czerwca 2018 r. w Sprawie Przyjęcia “Programu Działań Mających na Celu Zmniejszenie Zanieczyszczenia Wód Azotanami Pochodzącymi ze Źródeł Rolniczych Oraz Zapobieganie Dalszemu Zanieczyszczeniu" (Regulation of the Council of Ministers of 5 June 2018 on the Adoption of the "Action Program to Reduce Water Pollution with Nitrates from Agricultural Sources and to Prevent Further Pollution"). Dz. U. 2018, poz. 1339. Available online: https:/ / isap.sejm.gov.pl/isap.nsf/DocDetails.xsp?id=WDU20180001339 (accessed on 4 November 2020).

51. ZAŁACZNIK. Wspólny Format Krajowego Programu Ograniczania Zanieczyszczenia Powietrza na Podstawie Art. 6 Dyrektywy (UE) 2016/2284, Krajowy Program Ograniczania Zanieczyszczenia Powietrza (ANNEX Common format for a National Air Pollution Control Program Pursuant to Art. 6 of Directive (EU) 2016/2284, the National Air Pollution Control Program), 2019. Available online: https:/ / ec.europa.eu/environment/air/pdf/reduction_napcp/PL\%20final\%20NAPCP\%2027Jun19\% 20annexed\%20report.pdf (accessed on 4 November 2020).

52. International Organization for Standardization. ISO. 2019. Country Codes-ISO 3166. Available online: https://www.iso.org/ iso-3166-country-codes.html (accessed on 10 November 2020).

53. Wysocki, F.; Lira, J. Statystyka Opisowa (Descriptive Statistics); Wydawnictwo Akademii Rolniczej im. Augusta Cieszkowskiego: Poznań, Poland, 2005.

54. Luszniewicz, A.; Słaby, T. Statystyka z Pakietem Komputerowym STATISTICA PL. Teoria i Zastosowania (Statistics with the STATISTICA PL Computer Package. Theory and Applications); Wydawnictwo, C.H., Ed.; Beck: Warszawa, Poland, 2003. 
55. European Environment Agency. EEA 2020. Available online: https://europa.eu/european-union/about-eu/agencies/eea_en (accessed on 10 November 2020).

56. Zrównoważony Rozwój i Cele Zrównoważonego Rozwoju (Sustainable Development and Sustainable Development Goals); UNIC: Warszawa, Poland, 2015. Available online: http://www.unic.un.org.pl/strony-2011-2015/zrownowazony-rozwoj-i-cele-zrownowazonegorozwoju/2860 (accessed on 10 November 2020).

57. Kopeć, E. Regulacje Unii Europejskiej a wskaźniki gospodarki o obiegu zamkniętym w Polsce (European Union regulations and indicators of the circular economy in Poland). In Wskaźniki Monitorowania Gospodarki o Obiegu Zamkniętym (Circular Economy Monitoring Indicators); Kulczycka, J., Ed.; Instytut Gospodarki Surowcami Mineralnymi i Energia Polskiej Akademii Nauk IGSMiE PAN: Kraków, Poland, 2020; pp. 21-35.

58. Kulczycka, J. (Ed.) Wskaźniki Monitorowania Gospodarki o Obiegu Zamkniętym (Circular Economy Monitoring Indicators); Instytut Gospodarki Surowcami Mineralnymi i Energia Polskiej Akademii Nauk IGSMiE PAN: Kraków, Poland, 2020.

59. Kuznets, S. Economic Growth and Income Inequality. Available online: https://assets.aeaweb.org/asset-server/files/9438.pdf (accessed on 10 November 2020).

60. Fodha, M.; Zaghdoud, O. Economic growth and pollutant emissions in Tunisia: An empirical analysis of the environmental Kuznets curve. Energy Policy 2010, 38, 1150-1156. [CrossRef]

61. Ozcan, B. The nexus between carbon emissions, energy consumption and economic growth in Middle East countries: A panel data analysis. Energy Policy 2013, 62, 1138-1147. [CrossRef]

62. Jovanović, M.; Kašćelan, L.; Despotović, A.; Kašćelan, V. The Impact of Agro-Economic Factors on GHG Emissions: Evidence from European Developing and Advanced Economies. Sustainability 2015, 7, 16290-16310. [CrossRef]

63. Narayan, P.K.; Narayan, S. Carbon dioxide emissions and economic growth: Panel data evidence from developing countries. Energy Policy 2010, 38, 661-666. [CrossRef]

64. Wawrzyniak, D. Weryfikacja środowiskowej krzywej Kuznetsa dla krajów Unii Europejskiej. Ekonomista 2018, 3, 318-334.

65. Hamit-Haggar, M. Greenhouse gas emissions, energy consumption and economic growth: A panel cointegration analysis from Canadian industrial sector perspective. Energy Econ. 2012, 34, 358-364. [CrossRef]

66. Chen, J.; Liu, Y.J.; Pan, T.; Ciais, P.; Ma, T.; Liu, Y.H.; Yamazaki, D.; Ge, Q.S.; Penuelas, J. Global socioeconomic exposure of heat extremes under climate change. J. Clean. Prod. 2020, 277123275. [CrossRef]

67. Ziolo, M.; Kluza, K.; Spoz, A. Impact of Sustainable Financial and Economic Development on Greenhouse Gas Emission in the Developed and Converging Economies. Energies 2019, 12, 4514. [CrossRef]

68. Klepacki, B. Zrównoważony rozwój terenów wiejskich-wybrane aspekty teoretyczne (Sustainable development of rural areasSelected theoretical aspects). Roczniki Naukowe Stowarzyszenia Ekonomistów Rolnictwa i Agrobiznesu SERiA 2000, 2, 8-13.

69. Czudec, A.; Miś, T.; Zając, D. Zrównoważony Rozwój Obszarów Wiejskich w Wymiarze Regionalnym (Sustainable Development of Rural Areas in the Regional Dimension); Bogucki Wydawnictwo Naukowe: Poznań, Rzeszów, Poland, 2018; p. 7.

70. Janiszewska, D.A.; Ossowska, L. Zróżnicowanie rolnictwa krajów Unii Europejskiej na podstawie wybranych cech (Diversification of agriculture in the European Union on the basis of selected features). Zeszyty Naukowe SGGW w Warszawie, Problemy Rolnictwa Światowego 2014, 14, 45-54.

71. Janiszewska, D.A.; Ossowska, L. Wybrane aspekty oddziaływania rolnictwa na środowisko w państwach Unii Europejskiej (The Impact of Agriculture on the Environment in EU Countries-Selected Aspects). Zeszyty Naukowe SGGW w Warszawie, Problemy Rolnictwa Światowego 2017, 17, 73-83. [CrossRef]

72. Matyka, M. Stan rolnictwa w Polsce na tle Unii Europejskiej (The condition of agriculture in Poland compared to the European Union). In Studia Raporty; IUNG-PIB (Institute of Soil Science and Plant Cultivation State Research Institute): Puławy, Poland, 2014; Volume 40, pp. 9-28.

73. Mukumbuta, I.; Shimizu, M.; Hatano, R. Mitigating Global Warming Potential and Greenhouse Gas Intensities by Applying Composted Manure in Cornfield: A 3-Year Field Study in an Andosol Soil. Agriculture 2017, 7, 13. [CrossRef]

74. Communication from the Commission to the European Parliament, the Council, the European Economic and Social Committee and the Committee of the Regions "Stepping up Europe's 2030 Climate Ambition Investing in a Climate-Neutral Future for the Benefit of Our People". COM/2020/562 Final. Available online: https://ec.europa.eu/clima/sites/clima/files/eu-climateaction/docs/com_2030_ctp_en.pdf (accessed on 4 November 2020). 